\title{
Bernhard Häring CSsR na drodze ku nowej teologii moralnej
}

Działalność o. Bernharda Häringa przypadła na ciekawy i zarazem trudny czas w historii Kościoła katolickiego i katolickiej teologii moralnej. Były to lata bezpośrednio poprzedzające Sobór Watykański II, obejmujące jego przebieg i pierwsze dekady posoborowej odnowy ${ }^{1}$. W stuleciu od drugiej połowy XIX do drugiej połowy XX wieku Kościół rzymskokatolicki doświadczał daleko idących zmian. Należy najpierw wspomnieć upadek Państwa Kościelnego, zjednoczenie Włoch ${ }^{2}$ i dwie wojny światowe. Potem problemy wewnątrzkościelne, którym miał zaradzić pierwszy

Po śmierci papieża Jana Pawła I kandydatem ze strony kardynałów kurialnych był kard. Siri, znany krytyk Vaticanum II. „Gazetta del Popolo” opublikowała wywiad z nim, który redakcja dostarczyła kardynałom przed konklawe. Kard. Siri wypowiedział się w nim m.in. na temat kolegialności w Kościele katolickim, uznając ją po prostu za bezsens. Wywiad ten i program kard. Siri został negatywnie oceniony i w ten sposób droga na tron papieski dla kard. Karola Wojtyły stanęła otworem. Zob. B. Häring, Meine Erfahrungen mit der Kirche, Freiburg-Basel-Wien 1989, s. 7-8.

2 J. Gelmi, Das Papstum bis zum Ersten Weltkrieg, w: Das Papstum. Epochen und Gestalten, red. B. Moser, München 1983, s. 244-255. 
i drugi Sobór Watykański. Pierwszy był pierwszą próbą odpowiedzi Kościoła na pytania związane z modernizmem, podczas gdy drugi poszukiwaniem jego pozycji w świecie i próbą nawiązania z nim kulturowego kontaktu ${ }^{3}$. W historii teologii katolickiej stulecie to z jednej strony naznaczone było próbami pozbawienia jej naukowego charakteru przez zwolenników pozytywizmu i różnych ateizmów, a z drugiej strony było świadkiem odnowy teologii zaplanowanej przez papieża Leona XIII oraz papieży Soboru Watykańskiego II i pierwszych posoborowych dziesięcioleci. Te okoliczności tworzyły kulturowy klimat, w którym żył i tworzył o. Bernhard Häring ${ }^{4}$. Gdyby więc chciało się wyczerpująco przedstawić jego osobę i dzieło, należałoby - jako wprowadzenie - omówić znaczenie i osiągnięcia obu soborów, ważne elementy kultury i sytuację Kościoła katolickiego ze szczególnym uwzględnieniem katolickiej teologii moralnej, co w ramach niniejszego opracowania nie jest możliwe. Ograniczymy się zatem tylko do kontrowersji związanych z poglądami teologicznomoralnymi o. Häringa, które to kontrowersje towarzyszyły mu przez całe życie.

Pierwszy okres jego twórczości teologicznomoralnej, zakonczony publikacją Das Gesetz Christi, wprawił w zakłopotanie część ówczesnych teologów. Lata przygotowań i przebieg Soboru Watykańskiego II wyznaczają drugi okres, w którym doświadczał ze strony części teologów i urzędników Kurii Rzymskiej, a szczególnie Kongregacji Świętego Oficjum, przemianowanej na Kongregację Doktryny Wiary, czegoś więcej niż niechęci. Ważnym wydarzeniem w trzecim - ostatnim - okresie jego życia był proces wytoczony mu przez Kongregację Doktryny Wiary. Dla

\footnotetext{
Tamże, s. 263-274.

4 Tamże.
} 
ukazania atmosfery religijno-teologicznej, w jakiej żył i pracował o. Häring, w przypisach podano podstawowe informacje o najważniejszych osobach związanych z jego działalnością.

\section{Do Das Gesetz Christi}

Bernhard Häring urodził się 10 listopada 1912 roku jako jedenaste $\mathrm{z}$ dwanaściorga rodzeństwa, $\mathrm{z}$ których dwoje zmarło $\mathrm{w}$ wieku dziecięcym. Ojciec Bernharda Johannes był zadowolonym ze swego stanu rolnikiem. Jego ojciec z kolei był browarnikiem i właścicielem gospody. Dziadkowie znani byli Bernhardowi jedynie z opowiadań. Matka była gospodynią domową i wychowawczynią dzieci, bardzo cenioną przez męża. Było to małżeństwo prawdziwie partnerskie. Ojciec był raczej surowy, ale pod wpływem żony z biegiem czasu łagodniał. Trudno - napisał o. Bernhard - byłoby znaleźć lepszych rodziców. Ich dom znany był z gościnności, zwłaszcza wobec żebraków. Rodzina była względnie zamożna, chętnie pomagająca biednym. Dzieci wychowywano bez cienia jakiejkolwiek przemocy ${ }^{5}$.

Rodzice o. Häringa byli prawdziwie religijni, zdrową pobożnością, daleką od zabobonów i przesądów. Wieczorami, zwłaszcza w zimie, często odwiedzali ich sąsiedzi. Odmawiali wspólnie różaniec, czytali Pismo Święte i życiorysy świętych ${ }^{6}$.

Dzieciństwo Bernharda przypadło na lata pierwszej wojny światowej. Jego najstarszy brat spędził trzy lata na froncie zachodnim. Drugi w kolejności jeszcze przed osiągnięciem wieku zdatności do służby dobrowolnie - mimo sprzeciwu ojca - zgłosił się

\footnotetext{
B. Häring, Meine Erfahrungen mit der Kirche, dz. cyt., s. 21-22.

6 Tamże, s. 22-23.
} 
do wojska, by go zastąpić. Pod koniec wojny najstarszy syn zginął, a drugi nabawił się w jenieckim obozie angielskim poważnej choroby. Ojciec Bernharda - członek Partii Centrum - był zaangażowany politycznie. Jego dzieci zajmowały się roznoszeniem materiałów propagandowych. Ówczesne władze borykały się z bezrobociem, a komuniści cieszyli się rosnącą popularnością. Bernhard rozczytywał się w dziełach Karola Marksa. Miał też możliwość uczestniczenia w zebraniach partyjnych ${ }^{7}$.

W 1932 roku Häring napisał dramat Die soziale Tat, który kończy się zdaniem: „Söben ist die rote Armee in Königsberg eingezogen”. Nie spodziewał się wtedy, że w 1945 roku jako żołnierz pokonanej armii będzie uciekał przed Armią Czerwoną. Gdy po dojściu Hitlera do władzy w 1933 roku każda rodzina niemiecka otrzymała radioodbiornik w celach propagandowych, ojciec Bernharda powiedział, że dopóki Hitler będzie wrzeszczał przez radio, w jego domu nie będzie odbiornika. A gdy jego żona została odznaczona jako matka wielu dzieci, odmówiła przyjęcia tego odznaczenia, ponieważ - jak powiedziała - swoich dzieci nie rodziła dla narodowego socjalizmu ${ }^{8}$.

Po zdaniu egzaminu dojrzałości w państwowym gimnazjum (Günzburg) w marcu 1933 roku, i to jako najlepszy uczeń, Bernhard przeżywał pewne trudności związane $\mathrm{z}$ wyborem dalszego sposobu życia. Był przekonany, że świat potrzebuje głosicieli Ewangelii, i pełen podziwu dla jezuitów, zwłaszcza dla

Tamże, s. 23-24. „Ich fühlte mich nie zu Sympathien für den Marxismus versucht, lernte jedoch die Lektüre der Schriften von Marx und Engels jedem Versuch, Religion für die Ziele der Reichen und Mächtigen zu verwenden, zu widerstehen"; tamże, s. 24; tenże, Moraltheologie für das dritte Jahrhundert, Graz-Wien-Köln 1999, s. 9.

8 B. Häring, Meine Erfahrungen mit der Kirche, dz. cyt., s. 25. 
o. Mateusza Ricciego i św. Franciszka Ksawerego. Pod jego wpływem podjął zamiar wstąpienia do Towarzystwa Jezusowego, ale go nie zrealizował $\mathrm{z}$ powodu pewnej praktyki w tym zakonie. Otóż bardziej uzdolnieni byli w nim kierowani na drogę naukową, na co Bernhard nie miał ochoty. Wtedy spotkał prowincjała redemptorystów bawarskich, który go zapewnił, że w tym zgromadzeniu nie musi zostać profesorem. To zadecydowało o wstąpieniu Bernharda w 1934 roku do nowicjatu redemptorystów w Gars am Inn. Tak rozpoczął życie zakonne, choć w szkole podstawowej nic na to nie wskazywało. Był uczniem leniwym. Interesował się bardziej końmi w gospodarstwie ojca niż zadaniami domowymi. Mimo to jednak już w dwunastym roku życia - wspominał - pojawiła się u niego myśl o zostaniu misjonarzem9 ${ }^{9}$

W czasie jego nowicjatu odwiedził Gars kard. Faulhaber i od niego Bernhard usłyszał, że narodowy socjalizm jest właściwie zbiorem wszelkich herezji ${ }^{10}$. Po zajęciu Austrii przez Hitlera w niedalekim Gars zapanowały obawy i zniechęcenie. Redemptoryści bawarscy zajęli zdecydowanie negatywne stanowisko wobec tych wydarzeń. Z tego powodu schronienie w Gars znaleźli biskup Rottenburga Sproll oraz prof. Theodor Steinbüchel, późniejszy promotor doktoratu o. Häringa. Po złożeniu ślubów zakonnych prowincjał bawarskiej prowincji zachęcał Bernharda do nauki języka i kultury Brazylii, prosząc go równocześnie o zachowanie dyskrecji co do dalszych planów życiowych, w tym wyjazdu do Ameryki Południowej ${ }^{11}$.

9 „Du wirst von mir für längere Zeit keinen Brief mehr erhalten: denn mir stehen lägere Exerzitien auf dem Heuberg bevor (KZ)"; tamże, s. 25-27.

10 „Der Nationalsozialismus Hitlers ist nicht nur eine Häresie, sondern die Summe aller Häresien”; tamże, s. 27-28.

11 Tamże. 
Po zakończeniu nowicjatu Bernhard rozpoczął studia w Gars, a od 1936 roku studia teologii w zakonnej szkole wyższej. Profesor teologii moralnej był doktorem obojga praw i posługiwał się znanym podręcznikiem teologii moralnej autorstwa Aertnysa, co bynajmniej nie zachęciło go do studiowania tej właśnie dyscypliny teologicznej ${ }^{12}$. Podczas studiów interesował się historią, filozofią, socjologią, dogmatyką i przede wszystkim egzegezą biblijną. Był za to negatywnie nastawiony do teologii moralnej i prawa kanonicznego. W Niemczech bowiem coraz większego znaczenia nabierała inna teologia moralna, szczególnie uprawiana przez J.M. Sailera, J.B. Hirschera i F. Tillmanna, oraz etyka wartości M. Schelera i D. von Hildebranda. Mimo to Häring nie wykazywał większego zainteresowania studiami teologii moralnej ${ }^{13}$.

Po święceniach kapłańskich (maj 1936), mimo wcześniejszych obietnic prowincjała i przygotowań do wyjazdu do Brazylii, kolegium profesorów w Gars uznało o. Häringa za dobrego kandydata na wykładowcę teologii moralnej, co ten przyjął, kierując się ślubem posłuszeństwa, choć bez zbytniej radości. Prowincjał skierował go na dalsze studia na jednen $\mathrm{z}$ niemieckich uniwersytetów, a o. Häring wybrał Tybingę, zaś na promotora doktoratu prof. Steinbüchela ${ }^{14}$, znanego mu $\mathrm{z}$ lat wojennych, gdy ten ukry-

12 „Sicher, wir lieben Christus, aber nichts in aller Welt kann uns dazu bewegen, die Moral zu lieben”; tamże, s. 28-29; B. Häring, Moraltheologe für das dritte Jahrhundert, dz. cyt., s. 10-11.

13 B. Häring, Meine Erfahrungen mit der Kirche, dz. cyt., s. 29.

14 Theodor Steinbüchel, profesor teologii moralnej na Wydziale Teologii Uniwersytetu w Tybindze, w latach 1946-1948 jego rektor, potem prorektor. Myślą przewodnią teologii moralnej w jego wydaniu była idea naśladowania Chrystusa. Jako jeden z najważniejszych uczniów F. Tillmanna należał do wiodących przedstawicieli teologii moralnej ukierunkowanej biblijnie i równocześnie otwartej na odnowę. Taką postać otrzymała ona na Soborze Watykańskim II. Poza tym Steinbüchel podejmował próby 
wał się w Gars. Profesor zaproponował mu temat rozprawy doktorskiej Das Heilige und das Gute - das gegenseitige Verhältnis von Religion und Moral, wskazując równocześnie na Husserla i Schelera jako źródła problematyki ${ }^{15}$.

Tymczasem po wybuchu drugiej wojny światowej o. Bernhard znalazł się w pierwszej grupie duchownych powołanych do wojska. Zgodnie z postanowieniami konkordatu, mogli oni ubiegać się o pracę w służbach sanitarnych. Po ukończeniu studiów przełożeni o. Bernharda, dzięki osobistym kontaktom z lekarzem ze sztabu generalnego, wystarali się dla niego o urlop czasowy (styczeń-lipiec 1939). W tym czasie prowadził wykłady z teologii moralnej w zakonnej szkole wyższej w Gars. Równocześnie pracował nad planem Das Gesetz Christi ${ }^{16}$. We wrześniu 1940 roku zapisał się na Wydział Teologii w Tybindze z zamiarem pracy nad doktoratem, ale wkrótce został powołany do stacjonującej we Francji kompanii sanitarnej. Dowódcy jej byli mu przychylni i dlatego mógł prowadzić działalność duszpasterską. W każdą niedzielę odprawiał Mszę św. z kazaniem, w której uczestniczyła prawie cała kompania sanitarna oraz jednostki stacjonują-

przezwyciężenia ówczesnego, mającego dalekie konsekwencje podziału nauk: etykę i teologię moralną zaliczył do nauk humanistycznych. Przez całe życie zajmował się problemami istotnymi dla człowieka pytającego o najważniejsze sprawy życiowe i poszukującego zbawienia w historycznych i społecznych uwarunkowaniach. Zob. G.W. Hunold, Steinbüchel Theodor, w: LthK, t. 9, Freiburg-Basel-Wien-Rom 2000, kol. 948 (tam także twórczość).

15 B. Häring, Meine Erfahrungen mit der Kirche, dz. cyt., s. 29. O studiach teologii moralnej zob. tenże, Moraltheologie für das dritte Jahrtausend, dz.cyt., s. 9-17.

16 „Ich war fest entschlossen mich nicht lebensfremden Problemen herumzuschlagen, wärhrend die Welt in Flammen stand"; B. Häring, Meine Erfahrungen mit der Kirche, dz. cyt., s. 31 . 
ce w jej pobliżu. Po kilku tygodniach mógł odprawiać w katedrze w Bayeux, w czym pomagała mu znajomość języka francuskiego. $Z$ tego samego powodu otrzymywał wiele zadań wymagających kontaktów z miejscową ludnością, co zaowocowało serdecznymi przyjaźniami z niektórymi rodzinami i duchownymi. W maju 1941 roku dywizja, w której służył, została przerzucona do Polski nad granicę polsko-rosyjską. Tam o. Bernhard prowadził godziny biblijne, odprawiał Msze św. dla żołnierzy katolików. Uczestniczyli w nich również protestanci oraz wielu Polaków. W dzień wybuchu wojny z Rosją odprawił nocą Mszę św., w której uczestniczyli prawie wszyscy żołnierze, udzielił absolucji generalnej i komunii św. katolikom i protestantom. Później udzielał sakramentów również prawosławnym. Te doświadczenia były ważne dla późniejszej działalności ekumenicznej o. Bernharda i doprowadziły go do przekonania, że wszędzie są dobrzy i źli ludzie. Wszystkim udzielał porad duchowych, pomagał w uwalnianiu rosyjskich więźniów czy Żydów, czemu towarzyszyło poważne ryzyko. Doświadczał również dobroci ze strony Rosjan, zwłaszcza podczas walk pod Stalingradem, gdzie ratowali żołnierzy niemieckich przed głodem i śmiercią z wyziębienia. Po kapitulacji o. Bernhard dostał się do rosyjskiej niewoli, a podczas powrotu ze Wschodu doznał wiele dobroci od ludzi oraz łaski Opatrzności, co odbiło się później na jego pracy jako teologa moralisty ${ }^{17}$. Innym ważnym doświadczeniem tego okresu było absurdalne posłuszeństwo chrześcijan względem przestępczego rządu ${ }^{18}$.

17 Tamże, s. 31-35.

18 „Und das hat sich radical auf mein Denken und Handeln als Moratheologe ausgewirkt"; tamże, s. 35. Doświadczenia lat wojny Häring opisał w Als es um Überleben ging. Erinnerungen aus meienem Leeben 1939-1945, Stuttgart 1991. 
W czasie drugiej wojny światowej zło osiągnęło postać i wymiary dotąd nieznane. Po jej zakończeniu świat był już inny. Wraz $\mathrm{z}$ nim wobec konieczności zmiany stanęła również teologia moralna. O. Bernhard Häring po doświadczeniach wojny nie tylko nie utracił zapału duszpasterskiego, lecz jeszcze się w nim umocnił. W takim usposobieniu znalazł się w Stuttgarcie, we francuskiej strefie okupacyjnej. Tymczasem jego przełożeni zakonni potrzebowali profesora teologii moralnej i polecili mu kontynuować studia w Tybindze. Niemałą rolę odegrały w nich doświadczenia wojenne, wpływając na podkreślenie przez niego wagi odpowiedzialności, a nie posłuszeństwa, co zrodzi postawę odpowiedzialnego posłuszeństwa. Innym skutkiem udziału w wojnie było doświadczenie miłości uwalniającej od wrogości, prowadzącej do pojednania oraz uwolnienia ludzi od przemocy i to o. Bernhard uznał za zadanie teologii moralnej ${ }^{19}$.

Jak już wspomniano, o. Häring wybrał na promotora doktoratu prof. Steinbüchela. W Tybindze słuchał również wykładów

19, „...) meine Hauptberufung die eines unermündliches Friedensapostels für die Abschaffung des Krieges, für eine gewaltfreie Weltkultur, für eine radicale Liebe (...) ist und sein muss"; B. Häring, Meine Erfahrungen mit der Kirche, dz. cyt., s. 35-36. Motywem tego wyboru była najprawdopodobniej znana teologiczna szkoła tybińska, której tradycje do dziś kontynuuje Wydział Teologii Uniwersytetu w Tybindze. Wielkie znaczenie miały usiłowania przezwyciężenia przez jej przedstawicieli zwłaszcza oświeceniowego deizmu, co sprowadzało się do nowego ujęcia stosunku Boga do świata. Bóg nie jest względem niego „zewnętrzny”, a świat i człowiek są jakby organicznie ze sobą powiązani. W odniesieniu do Objawienia twierdzono, że jest ono dane przez Boga i wraz z chrześcijaństwem tworzy historyczną religię, dlatego jest poznawalne w kategoriach historii. Do tego dochodzi charakterystyczna dla tej szkoły metoda historyczno-krytyczna. Zob. H. Fries, Tübinger Schule, w: LThK, t. 10, Freiburg im Br. 1986, kol. 390-392; por. P. Colombo, Szkoła tybingeńska, w: Historia teologii, red. G. Angellini, G. Colombo, M. Vergottin, tłum. W. Szymona, t. IV, Kraków 2008, s. 293-328. 
innych znanych uczonych. Brał udział w zajęciach prowadzonych przez Romano Guardiniego oraz kilku profesorów protestanckich (Köberle, Thielicke i Rickert), co miało wielkie znaczenie dla jego późniejszej działalności ekumenicznej. W 1947 roku ukończył pracę nad doktoratem, ale rozprawę opublikował dopiero w 1950. Przywołał w niej sześciu niemieckojęzycznych myślicieli, to jest M. Schelera $\mathrm{z}$ katolickiego okresu jego twórczości ${ }^{20}$, I. Kanta, N. Hartmanna, świadomego i zdecydowanego fenomenologa ateistę oraz etyka wartości, dalej F. Schleiermachera, R. Otto i E. Brunnera, protestanckiego teologa personalistę. O. Häring nie zajął w niej postawy apologetycznej, jak to wówczas prawie powszechnie czyniono, lecz uczył się od inaczej myślących mistrzów. Po publikacji rozprawa ta spotkała się z pozytywnym odbiorem, czego wyrazem były jej przekłady na wiele języków współczesnych i alfabet Braille’a.

Od tego roku o. Häring rozpoczął nauczanie w Gars. Wykładał teologię moralną, filozofię moralności, socjologię rodziny i religii. Ponadto otaczał opieką duszpasterską uciekinierów wojennych, głosząc dla nich misje we współpracy z innymi redemptorystami, w tym znanym i cenionym o. V. Schurrem. W kazaniach misyjnych podejmowali tematy związane z ludzkimi problemami i poszukiwali odpowiedzi na dręczące ludzi pytania ${ }^{21}$.

Das Gesetz Christi o. Häringa powstawało w czasie wielkich przemian i rodzenia się „nowego świata”. Motywem jego napisa-

20 Warto przypomnieć, że prawie w tym samym czasie, kiedy o. Häring pisał rozprawę doktorską, ks. dr Karol Wojtyła pracował nad rozprawę habilitacyjną Ocena możliwości zbudowania etyki chrześcijańskiej przy założeniach systemu Maxa Schelera, ukończoną w 1953 roku.

21 B. Häring, Meine Erfahrungen mit der Kirche, dz. cyt., s. 37-40. Doktorat opublikowało wydawnictwo Erich Wewel. 
nia było przekonanie, że wcześniejsze książki z teologii moralnej nie odpowiadają już na nowe i aktualne pytania. Jako wykładowca na nowo opracowywał swe wykłady bez zamiaru ich wydania, ale uczynił to pod wpływem próśb studentów. Pracę nad tym dziełem intensywnie prowadził w 1948 roku, podczas pierwszego pobytu w Rzymie. Doświadczenia rzymskie potwierdzały jego przekonanie o konieczności odejścia w teologii moralnej od legalizmu, przy trwaniu w wierności wobec Pisma Świętego oraz podejmując problemy współczesnych ludzi. Korzystną okolicznością w Rzymie był dostęp do pozaniemieckiej literatury teologiczno-moralnej, zwłaszcza w bibliotece rzymskiego Uniwersytetu Gregoriańskiego. W Gars pomocą służył mu o. Schurr, klasztorna biblioteka, Stadtbibliothek w Monachium oraz profesorowie redemptoryści: o. Brandhuber i o. Schaumberger. Ten drugi, egzegeta i orientalista, pomagał o. Häringowi w zakresie teologii biblijnej. W 1953 roku manuskrypt był gotowy do druku i rok później się ukazał. O. Bernhard otrzymał za to opracowanie nagrodę wydawców Schönstes Buch des Jahres. W ciągu jednego roku ukazały się trzy wydania, później przełożono je na 14 języków, w tym japoński, chiński i polski. Do wydania francuskiego z 1955 roku przedmowę napisał kard. Garrone ${ }^{22}$.

W tym samym czasie przełożony generalny redemptorystów o. Leonard Buijs, wcześniej profesor teologii moralnej w Wittem (Holandia), powziął plan reformy studiów teologii moralnej w Zgromadzeniu. Dotąd biskupi i przełożeni zakonni kierowali kandydatów na profesorów teologii moralnej na studia prawa kanonicznego lub obojga praw w Rzymie i tym samym in-

22 Tamże, s. 40-41; 45-46. (Wydanie polskie: B. Häring, Nauka Chrystusa. Teologia moralna, tłum. i oprac. J. Klenowski, Pallottinum, Poznań 1962). 
stytucjonalnie powiązano ją z prawem kanonicznym. Tymczasem plan o. generała przewidywał przeniesienie studiów teologii moralnej na wydziały teologiczne i nadanie jej szerszego zakresu, $\mathrm{w}$ tym podjęcie problemów filozoficznych i teologiczno-dogmatycznych. Studium takie było przewidziane najpierw dla redemptorystów. Nie dziwi więc fakt powołania do Rzymu o. Häringa, teologa wykształconego w Tybindze. W 1948 roku o. Buijs zaproponował mu wykłady w jednym semestrze w planowanym studium, a może nawet na jednym $z$ wielu rzymskich uniwersytetów.

Po przybyciu do Rzymu o. Häring słuchał wykładów znanych i uznanych profesorów teologii, m.in. F.X. Hürtha i A. Vermeerscha, głównego redaktora encykliki Casti connubii. Hürth wykładał po łacinie w duchu kazuistycznym i nie dopuszczał słuchaczy do głosu. Podobnie postępował inny wybitny ówczesny teolog, Garrigou-Lagrange, który wykładał teologię dogmatyczną i mistykę. A przecież było o czym dyskutować. Jednym z gorących tematów była wydana w 1950 roku encyklika Humani generis. W Rzymie był wówczas Marín-Sola, dobry historyk dogmatów i dogmatyk, ale odmiennego zdania niż Garrigou-Lagrange. Został więc przez niego odesłany na Filipiny. Poza tym o. Häring wysoko cenił M.-D. Chenu, Y. Congara i H. de Lubaca. Już wtedy jednym z ważniejszych tematów teologicznomoralnych był problem grzechu, a ściślej określenie różnicy pomiędzy winą a chorobą ${ }^{23}$.

23 Tamże, s. 42-44 i 47. O sytuacji teologii moralnej w pierwszej połowie XX wieku zob. J.I. Saranyana, J.L. Illianes, Historia teologii, tłum. P. Rak, red. nauk. T. Dzidek, Kraków 1997; M. Alcala, La etica de situacion, Barcelona 1963; Pius XII, AAS 44 (1952), s. 270-271, 413-419; AAS 48 (1956), s. 144-145; DS 3918-3921; L. Melina, Morale tra crisi e rinovamento, Milano 1952; E. Molina, La moral entrela conviccion y a utilidad, Pamplona 1996; Sittliche Normen. Zum Problem ihrer allgemeiner und unwadelbarer Geltung, red. P.W. Werker, Düsseldorf 1982. 
W latach 1950-1953 o. Häring co roku jeden semestr przebywał w Rzymie jako profesor teologii moralnej w Akademii Alfonsjańskiej. Początkowo studiowali tam tylko redemptoryści oraz kilku duchownych diecezjalnych z Holandii. W wykładach o. Häring podejmował kwestię nawrócenia jako podstawowej perspektywy chrześcijańskiej teologii moralnej oraz obecności myśli protestanckiej i prawosławnej w katolickiej teologii moralnej. Problem nawrócenia znalazł się również w Das Gesetz Christi. Drugi temat wzbudził wielkie zainteresowanie i zaskoczenie studentów przyzwyczajonych do apologetyczno-obronnego traktowania innych niż katolickie wyznań chrześcijańskich. Niektórzy nawet posądzali o. Häringa o kryptoluteranizm. Podobne idee prezentował P. Lyonnet w rzymskim Instytucie Biblijnym ${ }^{24}$.

W 1953 roku zmarł o. Buijs. Kolejna Kapituła generalna Zgromadzenia podkreśliła znaczenie Akademii Alfonsjańskiej dla redemptorystów jako instytucji naukowej przygotowującej dobrze wykształconych profesorów teologii moralnej, jednak przez kolejne cztery lata akademia nie działała. Czas ten o. Häring wykorzystał na przygotowanie się do dalszej pracy, zwłaszcza studiując problemy społeczno-pastoralne i kończąc Das Gesetz Christi ${ }^{25}$. Dzieło to mimo wysokich ocen spotkało się z niechęcią niektórych rzymskich profesorów i urzędników Kurii Rzymskiej z powodu jego nowatorskiego charakteru. Wystarczy przypomnieć treść tomu pierwszego Zasadnicza postać chrześcijańskiego życia. Teologia moralna ogólna, by się przekonać o jego nowości ${ }^{26}$. War-

24 B. Häring, Meine Erfahrungen mit der Kirche, dz. cyt., s. 45-46.

25 Tamże, s. 46-47.

26 Część pierwsza nosi tytuł Wezwanie Chrystusa i omawia następujące zagadnienia: człowiek wezwany do naśladowania Chrystusa (istota i cel człowieka, indywidualność, osoba i społeczność podmiotem moralnej wartości, człowiek a historia, człowiek a kult); właściwa siedziba czynu 
to też rzucić okiem na spis treści innego ówczesnego podręcznika teologii moralnej, popularnego trzytomowego Summa theologiae moralis H. Noldina, by zobaczyć, jak bardzo się różni od propozycji Das Gezetz Christi ${ }^{27}$.

$\mathrm{W}$ tych latach o. Häring nawiązał też wiele kontaktów z wiodącymi przedstawicielami niemieckich związków zawodowych. W tych środowiskach wygłaszał prelekcje, kursy i prowadził dys-

moralnego (ludzka wolność - źródło czynu moralnego, poznanie dobra moralnego, moralne uzdolnienie człowieka - sumienie, pojedynczy akt oraz czynność podmiotem moralnej wartości, usposobienie); forma i treść wezwania Chrystusowego (norma a prawo, przedmiot moralny sam w sobie i w sytuacji, moralny motyw, zagadnienie czynu obojętnego, wzajemny stosunek przedmiotu, okoliczności i motywy); odpowiedź człowieka: odpowiedź negatywna - grzech (istota i następstwa grzechu: porzucenie i osłabienie naśladowania Chrystusa, podział grzechów); nawrócenie (wezwanie i podjęcie naśladowania Chrystusa, akty nawracającego się, wyznanie grzechów, zadośćuczynienie i pokuta, rozgrzeszenie i pojednanie); zasadnicze warunki coraz bardziej doskonałej odpowiedzi pozytywnej (cnota jako taka, ilość cnót, cnoty nabyte i wlane). Nieco później ks. Stanisław Olejnik wydał podręcznik, którego już sam tytuł wskazuje na nowe podejście do moralności: W odpowiedzi na dar i powołanie Boże. Zarys teologii mralnej, ATK Warszawa 1978.

27 A oto ów spis: De fine hominis ultimo; De actibus ad finem aptis; De legibus; De conscientia; De virtutibus; De peccatis; De praeceptis virtutum theologicarum; De praeceptis fidei; De praeceptis spei; De praeceptis caritatis; De praeceptis decalogi; De secundo decalogi praecepto; De tertio decalogi praecepto; De quarto decalogi praecepto; De quinto decalogi praecepto; De septimo decalogi praecepto; De octavo decalogi praecepto; De praeceptis ecclesiae; De abstinentia et iejunio; De annua confessione et de comunione paschali; De prohibitione librorum; De praecepto sustinendi pastores; De prohibitione cremandi cadavera; De praeceptis particularibus; De praeceptis laicorum; De praeceptis clericorum; De sacramentis; De sacramentis in genere; De baptismo; De confirmatione; De eucharistia; De paenitentia; Appendix I: De occasionibus particularibus; Appendix II: De confessione generali; De extrema unctione; De ordine; De matrimonio; De VI et IX praecepto; De usu matrimonii; De censuris et poenis; De censuris in genere; De censuris in specie. 
kusje. Po opublikowaniu książki Macht und Ohnmacht der Religion ożywiły się jego kontakty z chrześcijańsko-demokratycznym politykiem Alcidem de Gasperim (zm. 1954) ${ }^{28}$. Równocześnie studiował i wykładał socjologię religii. Watykan trzymał się z dala od polityki. Święte Oficjum wydawało wprawdzie wskazania dla polityków, ale pozostawały one bez echa. Postulowano ekskomunikowanie komunistów, co było ważne z powodu wzrostu znaczenia partii komunistycznej we Włoszech, ale taka postawa wzmacniała tendencje antyklerykalne, powodując niechęć do poruszania $\mathrm{z}$ ambony problemów politycznych oraz wzrost współczucia dla komunistów. Dla chrześcijańskich demokratów, którzy utożsamiali się z katolikami, wielkie znaczenie miał list pasterski kard. Montiniego - późniejszego papieża Pawła VI pod tytułem An die Kirchenfremden.

Tymczasem w Rzymie odezwały się głosy sprzeciwu wobec prób „nowej teologii” i podejrzanych profesorów. Garrigou-Lagrange oskarżał o nieprawowierność niektórych wykładowców. W kontekście encykliki Humani generis wyrażano obawę przed etyką sytuacyjną, ale $z$ drugiej strony odczuwano brak refleksji o znaczeniu kontekstu kulturowego oraz o rozwiązaniu konfliktu pomiędzy wartościami i normami, co zakładało zmienność norm ${ }^{29}$.

W roku śmierci Piusa XII rzymska teologia była w głębokim kryzysie. Dogmatykę uprawiano w kontekście encykliki Humani generis, a teologia moralna była pełna przestróg przed etyką sytuacyjną, ale nie brakło również myśli o inkulturacji oraz ukierunkowaniu teologii moralnej na jej historię. Wielką popularnością cieszyła się pobożność maryjna, która po ogłoszeniu dogma-

28 B. Häring, Meine Erfahrungen mit der Kirche, dz. cyt., s. 49-50.

29 Tamże, s. 47. 
tu o wniebowzięciu Maryi z ciałem i duszą osiągnęła apogeum. W tym smutnym położeniu teologii dawały jednak o sobie znać zwiastuny nowości. I tak reforma liturgiczna Wielkiego Tygodnia zintensyfikowała oczekiwanie odnowy całej liturgii, mimo wielu zakazów pochodzących z Watykanu. Encyklika Divino afflante Spiritu (1943) stała się początkiem biblijnej odnowy teologii. Sam Pius XII w swoich przemówieniach podkreślał znaczenie dla życia Kościoła publicznej wymiany poglądów oraz zastosowanie zasady pomocniczości w katolickiej nauce społecznej również w odniesieniu do struktur Kościoła. Z drugiej strony, wzmocniono centralizm w zarządzaniu Kościołem. Znaczącym wydarzeniem było przerwanie eksperymentu księży robotników. Nie bez znaczenia była sama osoba Ojca świętego, wywodzącego się z rodziny arystokratycznej, dobrze wykształconego dyplomaty. Niektórzy widzieli w nim nawet model papieża ${ }^{30}$.

\section{Do Soboru Watykańskiego II}

Papieże Jan XXIII i Paweł VI Das Gesetz Christi potraktowali jako ważny wkład w przygotowanie Soboru Watykańskiego II. Jan Paweł I, jako profesor teologii moralnej, dzieło to uznał za podręcznik tej dyscypliny ${ }^{31}$. Jednym słowem, należy stwierdzić, że o. Häringa nie da się pominąć w historii Soboru Watykańskiego II. Jako teolog i nauczyciel akademicki - niezależnie od opinii na temat jego poglądów - był zatroskany o zbawienie ludzi, o wzbudzenie świadomości odpowiedzialności historycznej we wszystkich dziedzinach teologii i życia. Oddziaływał przez liczne

30 Tamże, s. 52-53.

31 Tamże, s. 11-12. 
teksty, zwłaszcza Frei in Christus. Współpracował z czasopismem „Famiglia Cristiana”. Prowadził wykłady na całym świecie. Miał umiejętność słuchania prostych ludzi ${ }^{32}$.

Sytuacja zmieniła się po wyborze Jana XXIII. W Bolonii odbyła się konferencja socjologów religii, podczas której poszukiwano możliwości wykorzystania w duszpasterstwie socjologii religii, co dla Kurii Rzymskiej było podejrzane. Sam Jan XXIII wysoko cenił socjologów religii, teologów moralistów i pastoralistów jako dar Boga i znak nadziei dla Kościoła. Zwołując sobór powszechny, papież zaskoczył Kościół i świat przede wszystkim swoim optymizmem. Już sama lista biskupów i teologów powołanych do komisji przygotowującej sobór dla wielu była jak zimny prysznic. Sprawami wiary i moralności mieli się zająć m.in. Y. Congar, H. de Lubac i B. Häring. Święte Oficjum wyrażało wobec tych nazwisk sprzeciw, co było wynikiem ostrej walki dwóch skrajnych ugrupowań teologów i biskupów. O. Häring, profesor rzymski, dzięki dobrej znajomości łaciny miał przewagę nad biskupami spoza Włoch. Pierwsze propozycje przygotowane przez Święte Oficjum wywołały prawdziwą burzę. W schemacie dogmatycznym o grzechu pierworodnym wiele miejsca poświęcono Adamowi, a niewiele Chrystusowi, co prowadziło do przekonania, że „Pierwszy Adam” był ważniejszy od „Drugiego”. Podobnie było z dogmatycznym schematem o pośmiertnym losie dzieci nieochrzczonych. M. Schmaus, konsultor komisji przygotowawczej, wyrażał przekonanie, że dzieci nienarodzone i narodzone, ale zmarłe bez chrztu, są wykluczone z uczestnictwa we wspólnocie zbawionych, ale nie ponoszą kar wiecznych. Wyjątkiem są

32 „(...) er vor allem die Kunst beherrscht, (...) ganz besonders auf die einfachen Leute, zu hören. (...) Er wiederholt nicht nur die immer schon betonten Prinzipien, sondern trifft die Menschen in ihrer konkreten Lage"; tamże, s. 12. 
obrzezane dzieci żydowskie urodzone przed założeniem Kościoła. O. Häring ostro się temu sprzeciwił, powodowany osobistym doświadczeniem. Najstarsza jego siostra urodziła bliźniaki, ale jeden przyszedł na świat żywy, a drugi martwy i miejscowy proboszcz przekonywał ją, że nieżywe i nieochrzczone dziecko nie uczestniczy w zbawieniu wiecznym i nie może być pogrzebane po katolicku. Bernhard miał wtedy 14 lat $^{33}$.

O. Häring u podstaw zasygnalizowanych powyżej problemów widział fałszywy obraz Boga, pomijanie faktu Jego powszechnej woli zbawczej. Tymczasem kard. Ottaviani ${ }^{34}$ stwierdził, że w tym zagadnieniu, od dawna już rozstrzygniętym, powinno się o. Häringowi odebrać głos, na co ten odpowiedział, że ten problem ma rozstrzygnąć sobór powszechny. $\mathrm{M}$. Schmaus ${ }^{35}$ na te słowa opuścił salę zebrań komisji przygotowawczej i udał się do Monachium, a prowincjałowi redemptorystów bawarskich powiedział, że wątpi, by o. Häring przetrwał sobór w spokoju ${ }^{36}$.

33 Tamże, s. 53-55.

34 Alfredo Ottaviani (zm. 1979) w latach 1959-1968 był prefektem Kongregacji Świętego Oficjum (późniejszej Kongregacji Doktryny Wiary), od 1959 roku przewodniczącym komisji teologicznej dla przygotowania Soboru Watykańskiego II, w 1962 przewodniczącym analogicznej komisji soborowej. Sam nazwał siebie „strażnikiem” skarbca wiary. Był jednym z najbardziej bezkompromisowych wrogów komunizmu, sprzeciwiał się albo przynajmniej był sceptyczny wobec wschodniej polityki Pawła VI. Zob. J. Gelmi, Ottaviani Alfredo, w: LthK, t. 7, Freiburg-Basel-Rom-Wien 1998, kol. 1217-1218.

35 Michael Schmaus (zm. 1993), teolog katolicki, konsultor papieskiej komisji przygotowawczej Soboru Watykańskiego II, a od 1962 ekspert soborowy. Jego uczniem był m.in. J. Ratzinger. Zob. K. Góźdź, Schmaus Michael, Encyklopedia katolicka, t. 17, Lublin 2012, kol. 1208-1209.

36 „(...) die Unglaubwürdigkeit des allgemeinen Heilswillen Gottes, wenn nicht erfüllbare Bedingungen von Gott gesetzt würden. (...) Ich zweifle, ob Pater Häring das Konzil überleben wird”; B. Häring, Meine Erfahrungen mit der Kirche, dz. cyt., s. 55-56. 
Schemat dogmatyczny (Schema dogmaticum) spotkał się ze sprzeciwem ze strony o. Häringa, Y. Congara i innych teologów, lecz mimo to przekazano go do Centralnej Komisji Przygotowawczej. O. Häring odrzucił poglądy kard. Ottavianiego, autora projektu, na podstawie trzech twierdzeń. Pierwsze dotyczy powszechnej woli zbawczej, drugie przypomina o odkupieńczej śmierci Chrystusa podjętej za wszystkich ludzi, a trzecie - charakterystyczne dla duchowości redemptorystów - mówi o obfitym Odkupieniu. Tekst przedstawiający te trzy argumenty autorzy przekazali kard. Döpfnerowi ${ }^{37}$ i dwóm innym kardynałom. Ostatecznie trafil on do $\operatorname{archiwum}^{38}$.

Inne doświadczenie $\mathrm{z}$ okresu przedsoborowego związane było z osobą abpa Maksymiliana Hermaniuka, redemptorysty z Kościoła unickiego i wybitnego egzegety. Jako pierwszy wprowadził on pod obrady temat kolegialności w zarządzaniu Kościołem. Święte Oficjum uznało to zagadnienie za niewarte wysiłku. Teologiczna komisja przygotowawcza zdecydowanie negatywnie odniosła się do propozycji abpa Hermaniuka, ale o. Häring usłyszał od Y. Congara, że jest to wielki temat tego soboru. Podobnie uważał H. de Lubac - i wkrótce przeniesiono go do konwentu bez naukowej biblioteki ${ }^{39}$.

37 Julius Döpfner (zm. 1976), arcybiskup Monachium i Fryzyngi, działał $\mathrm{w}$ przedsoborowych komisjach przygotowawczych, a na Soborze Watykańskim II był jednym z czterech moderatorów. Interesował się socjologiczno-pastoralnymi analizami sytuacji w Kościele, formami i możliwościami działania Kościołów w świecie i kierunkami w duszpasterstwie. Zob. B. Łomacz, Döpfner Julius, Encyklopedia katolicka, t. 4, Lublin 1985, kol. 118-118.

38 B. Häring, Meine Erfahrungen mit der Kirche, dz. cyt., s. 56.

39 Tamże, s. 56-57. 
Inny biskup - Stohr - po ostatnim posiedzeniu komisji przygotowawczej z jego udziałem poprosił o. Häringa, by nie tracił cierpliwości do dalszych wysiłków, gdyż w przeciwnym wypadku sznur na szyi wiernych zostanie zaciśnięty tak mocno, że nie będą mogli oddychać ${ }^{40}$.

W komisji przygotowawczej istniały dwie podkomisje: De ordine morali oraz komisja do spraw związanych z celibatem, dziewictwem, małżeństwem i rodziną. Pracami ich kierowali dwaj konsultorzy Świętego Oficjum: F.X. Hürth, doradca papieża Piusa XII do problemów moralnych, oraz A. Vermeersch, główny redaktor encykliki Casti connubii, oraz Ermenegildo Lio, autor obszernej publikacji wydanej w Libreria Vaticana Humanae vitae e infallibilità (1986). O. Häring został powołany do tych podkomisji po przedyskutowaniu propozycji De ordine morali. Zwrócono w niej uwagę na dwuznaczność pojęcia amor i dlatego zaproponowano, by je zastąpić terminem „obowiązek”. Natomiast podkomisja do spraw celibatu i dziewictwa negatywnie oceniła wyrażenie św. Augustyna Ama et quod vis fac, na co o. Häring przypomniał św. Alfonsa, który często przytaczał pisma biskupa Hippony, a sam poświęcił miłości dzieło $O$ umiłowaniu Pana Jezusa i domagał się, by nie odchodzić od Jezusa na rzecz nauki o obowiązku, mającej korzenie kantowskie. Jeszcze gorsza sytuacja w podkomisji do spraw celibatu i dziewictwa wiązała się z odrzuceniem miłości jako istotnej postawy w małżeństwie. Powodem tego były trudności w kanonicznych procesach, wynikające z braku dowodów jej obecności lub nieobecności w małżeństwie. O. Häring uznał takie sformułowanie za skandal w chrześcijaństwie. W jego projekcie w punkcie wyjścia

40 „(...) der Strich um den Hals nicht so eng angezogen werde, dass sie keine Luft mehr bekämen”; tamże, s. 57. 
znalazło się pojęcie prawdziwej miłości, co o. Hürth uznał za sprzeczne z nauką Kościoła, a był on - jak nazwał go kard. Ottaviani - „kolumną Świętego Oficjum”41.

Przed rozpoczęciem Soboru o. Häring zastanawiał się nad losem 70 przygotowanych propozycji. Sądził, że szanse na przyjęcie ma tylko tekst o odnowie liturgii. Kardynałowie Suenens ${ }^{42}$ i Döpfner poprosili go o kontakt z zaprzyjaźnionymi z nim biskupami z obu Ameryk w celu uzyskania ich opinii o propozycjach przygotowanych dla Soboru i o możliwości ich przyjęcia. Oni także wyrazili przekonanie, że jedynie tekst o odnowie liturgii prawdopodobnie zostanie przyjęty, i tak też się stało, w głosowaniu dwoma trzecimi głosów. Kard. Suenens nazwał wtedy o. Häringa „beznadziejnym optymistą”. Równocześnie Święte Oficjum stawiało pod jego adresem kolejne zarzuty i wymaganie, by każdy uprawniony do pracy w komisji przygotowawczej zobowiązał się do przyjęcia tekstów zaproponowanych przez komisję $e^{43}$.

41 Papież Jan XXIII bezsprzecznie miał wpływ na prace przygotowawcze do soboru. Jest to zagadnienie obszerne i wymagające dokładnych studiów. O. Häring podaje jako przykład audiencję dla członków wszystkich komisji przygotowawczych, podczas której Jan XXIII przeczytał długi tekst i skomentował go, mówiąc, że Kościół nie jest muzeum; tamże, s. 57-59.

42 Léon-Joseph Suenens (zm. 1996) od 1940 był prorektorem uniwersytetu w Lowanium, a od 1943 rektorem. Paweł VI ustanowił go jednym z moderatorów Soboru Watykańskiego II. Kard. Suenens zaznaczył swój wpływ w soborowych dokumentach: Lumen gentium (Kościół ad intra oraz Kościół ad extra), Gaudium et spes, a także w odnowie liturgii i ruchu ekumenicznym oraz charyzmatycznym. Promował dialog ekumeniczny i międzyreligijny. Podkreślał rolę laikatu, kolegialność w zarządzaniu Kościołem, współodpowiedzialność, wolność religijną. Zob. P. Sokołowski, Suenens Leo Jozef, Encyklopedia katolicka, t. 18, Lublin 2013, kol. 1164-1165.

43 B. Häring, Meine Erfahrungen mit der Kirche, dz. cyt., s. 60-61. 
Po wyborze członków komisji soborowych Kuria Rzymska ogłosiła listy propozycji odpowiadających ich zapatrywaniom. $\mathrm{Na}$ przewodniczących wybrano kard. Liénarta z Lille i kard. Fringsa z Kolonii. W dzień wyborów przyjęto postulat, by każdego dnia miała miejsce przerwa dla ustalenia stanowisk. L. Capovilla, sekretarz Jana XXIII, zaprzyjaźniony z o. Häringiem, przekazał mu, że papież był zadowolony z takiego obrotu sprawy. Biskupi włoscy, podzieleni na trzy grupy, nie weszli na żadną listę ogólną. Wtedy o. Häring zwrócił się z prośbą do kard. Fringsa, by wpisać ich na listy Europy Północnej, Europy Środkowej oraz Ameryki Łacińskiej, i tak się też stało ${ }^{44}$.

Pierwsze posiedzenie Komisji ds. Wiary i Moralności było burzliwe. Trzech przedstawicieli Świętego Oficjum - Ottaviani, Parente i Tromp - przemawiało po ok. 30 minut na temat moralnego obowiązku przyjęcia przygotowanych tekstów z ewentualnymi nieznacznymi poprawkami i dyskusją na ich temat podczas obrad. Na to kard. Léger z Kanady oświadczył, że wobec tego może natychmiast wracać do siebie ${ }^{45}$.

44 Kard. Léon Duval z Algierii poprosił o. Häringa o ocenę propozycji teologicznomoralnych i przekazanie jej francuskojęzycznym biskupom z Afryki. O. Häring gotów był taką opinię sporządzić, ale pod warunkiem, że jeśli zaproponowane teksty zostałyby przyjęte, to po soborze kard. Duval umożliwi mu głoszenie Ewangelii w Afryce; tamże, s. 61.

45 Tamże, s. 62. O. Häring miał również kontakty z polskimi biskupami. Przypomniał tu wydarzenie z 1945 roku, kiedy to parafia polska „wykradła” go z obozu jenieckiego i przyjęła jako duszpasterza. Zauważył też, że kard. Stefan Wyszyński był mu bardzo życzliwy, o czym świadczy możliwość wydania polskiego tłumaczenia Das Gesetz Christi oraz innych książek czy zaproszenie do wygłoszenia wykładu dla wszystkich polskich biskupów podczas soboru w Rzymie; a biskupi polscy złożyli obietnicę wysyłania duchownych na studia w Akademii Alfonsjańskiej w Rzymie. 
O. Häring nie zabiegał o osobiste kontakty z Janem XXIII. Capovilla, sekretarz papieża, poinformował go, że ten bardzo ceni jego zabiegi w procesie odnowienia teologii moralnej. Niedługo po otwarciu soboru o. Häring wygłosił dla biskupów francuskojęzycznych komentarz do przemówienia papieża na rozpoczęcie soboru. Opublikował również książkę Il Concilio nel segno dell' unita (Konzil im Zeichen der Einheit), którą jeden z jego przyjaciół przekazał papieżowi. W dniu podpisania encykliki Pacem in terris Jan XXIII napisał w dzienniku o wielkiej radości, z jaką czytał tę książkę. Za pośrednictwem Capovilli o. Häring przekazał papieżowi to dzieło jako podarunek dla jego gości. Sam Jan XXIII był przekonany o konieczności odnowienia teologii moralnej. Znał również Das Gesetz Christi. Poza tym o. Häring przyjął z zadowoleniem fakt, że Jan XXIII powierzył komisji mieszanej przepracowanie projektu o Piśmie Świętym i Tradycji, w której miał swoich przedstawicieli Sekretariat ds. Jedności Kościoła. Był to wyraz myślenia ekumenicznego ${ }^{46}$.

Trzeba też powiedzieć, że o. Häring nie poszukiwał kontaktów z innymi wybitnymi osobistościami kościelnymi, ale miał ich wiele. Na przykład z kard. Montinim spotykał się jeszcze w czasach, gdy ten był arcybiskupem w Mediolanie ${ }^{47}$.

46 Tamże, s. 63-64.

47 Dwa razy w miesiącu o. Häring wygłaszał konferencje duchowe w Collegio Lombardo, gdzie kard. Montini mieszkał podczas swoich pobytów w Rzymie. Kardynał brał w nich udział, a potem, przy wspólnej kolacji, prowadzili rozmowy, poruszając często problemy związane $\mathrm{z}$ nadchodzącym soborem. Były one bardzo gorące po opublikowaniu książki o. Lombardiego z konkretnymi propozycjami, skrytykowanej przez „L'Osservatore Romano”. O. Häring zaakceptował te propozycje, a nawet uczynił je przedmiotem wykładów w Instytucie Pastoralnym Uniwersytetu Laterańskiego, skierowanych do kilkuset księży. O tych wykładach było głośno w Rzymie; tamże, s. 64 . 
Obrady soboru toczyły się podczas posiedzeń otwartych i w pracach komisji. Ich wspólną cechą była wierność przemówieniu Jana XXIII wygłoszonemu na jego otwarcie. W Komisji Teologicznej przyjęto je bez entuzjazmu, wręcz chłodno. Tę atmosferę przełamał kard. Léger. O. Häring, zachęcony przez biskupów, w niektórych momentach grał rolę błazna-mędrca. Kiedy o. Sebastian Tromp chciał zakończyć dyskusję stwierdzeniem, że jest niepotrzebna, gdyż rzecz jest całkiem pewna (certissimum), o. Häring je podważyl, zwracając uwagę na możliwość wątpienia. Jan XXIII powołał o. Häringa do pracy w Komisji Teologicznej jako peritus, co nie było po myśli kard. Ottavianiego. Tematem prac tej komisji podczas pierwszej sesji i w następnym okresie był radykalnie nowy podział propozycji dotyczących Kościoła. Na początku zaproponowano nową definicję: przez Kościół rozumie się nie papieża i Kurię Rzymską, lecz całość pielgrzymującego ludu Bożego, wspólnotę wiary i zbawienia. Zmiana myślenia przychodziła z trudem, zwłaszcza urzędnikom kurialnym. Kard. Ottaviani często upominał komisję, by rozpoczynała dyskusję o Kościele od papieża i Kurii Rzymskiej, a dopiero później przechodziła do mowy o wierzącym ludzie Bożym. W odpowiedzi bp Schröffer, późniejszy kardynał kurialny, mocno podkreślał, że papież i kardynałowie również należą do wierzących. Teksty robocze zostały napisane ze stałą krytyczną uwagą, by zawsze brać pod uwagę tożsamość papieża, Kurii Rzymskiej i Kościoła. To niebezpieczeństwo - według o. Häringa - trwa do dziś, czego przykładem jest rozumienie wystąpienia z Kościoła, ponieważ zdaniem przeciwników nowej nauki o Kościele tworzy go przede wszystkim Kuria Rzymska i Watykan. Tymczasem w rozdziale II 
konstytucji Lumen gentium, traktującym o aktywności świeckich w Kościele, była najpierw mowa o perspektywach. Było to jeszcze za życia Jana XXIII. Dalsze prace nad rozdziałem o powszechnym powołaniu do świętości komisja prowadziła latem w hotelu Santa Marta, gdy papież był już śmiertelnie chory ${ }^{48}$.

Po śmierci Jana XXIII o. Häring był przekonany o kontynuowaniu soboru w tym samym duchu. Możliwymi następcami papieża mogli być kard. Montini i kard. Lercaro, który wymówił się słabym zdrowiem, i tak Montini został Pawłem VI. Takiego wyniku konklawe oczekiwał Jan XXIII. Dla wielu ten wybór dawał nadzieję, że sobór będzie kontynuowany w dotychczasowym duchu, choć nie bez przeszkód. Według o. Häringa, najtrudniejszymi zagadnieniami w następnym okresie prac soborowych będzie widzenie ekumenizmu, kolegialność w życiu i zarządzaniu Kościołem, rola świeckich w Kościele, stosunek Kościoła do świata i zagadnienie wolności religijnej ${ }^{49}$.

Wielkie znaczenie dla dalszych prac soboru miał wybór przez papieża moderatorów obrad. Zostali nimi kardynałowie Döpfner, Lercaro, Suenens. Poza tym Paweł VI powołał Centralną Komisję, która 70 tekstów roboczych zredukowała do 13, wybrała tematy do dalszych prac, ustaliła program i cel soboru: gruntowną reformę Kościoła oraz zjednoczenie chrześcijan. W ten sposób zaakceptowano drogę Kościoła w aspekcie historii zbawienia i teologię zbawienia jako podstawową naukę. Za takim ukierunkowaniem opowiedziała się większość Komisji ds. Wiary i Moralności, podczas gdy niektórzy członkowie Świętego Oficjum, zbyt

\footnotetext{
48 Tamże, s. 65-66.

49 Tamże, s. 66-67.
} 
przywiązani do centralistycznej i absolutnej kontroli, próbowali bronić Kościoła jako „twierdzy” i posiadacza wszelkiej prawdy. Kolejnym problemem była kolegialność w zarządzaniu Kościołem i prawo synodalne, a jego rozwiązanie było uwarunkowane koniecznością nowej pneumatologii z twierdzeniem o zaufaniu Duchowi Świętemu, który działa we wszystkich i przez wszystkich, udzielając im obficie darów łaski. W zaufaniu Duchowi i mocy „prawa łaski” można i musi się odejść od instytucjonalnego i centralistycznego zapewnienia jedności Kościoła. W tej dziedzinie o. Häring był przekonany, że katolicy mogą się wiele nauczyć od prawosławnych. Podczas nadzwyczajnego Synodu Biskupów 20 lat po soborze kard. Garrone oświadczył, że przeżycie nawrócenia i uznanie rozstrzygnięć soborowych będzie długo oczekiwane ${ }^{50}$.

Paweł VI odznaczał się cierpliwością w dyskusjach o kolegialności i wolności religijnej. Był gotów czekać z decydującym głosowaniem tak długo, aż osiągalna stałaby się większość dwóch trzecich głosów. Nie chciał podziału na zwycięzców i pokonanych. Za tym myśleniem opowiedziała się zdecydowana większość ojców soborowych. Staranie o poprawny stosunek i zakres kolegialności między papieżem i biskupami, między biskupami i prezbiterium oraz między duszpasterzami a parafianami było naznaczone wieloma trudnościami. Przede wszystkim długotrwałe i instytucjonalne modele myślenia okazały się niemożliwe do szybkiej zmiany. Potrzeba było dużo czasu na przedyskutowanie kolegialności biskupów. Zwracano uwagę na konieczność pozostawania pod kierownictwem papieża, nigdy bez niego, oraz podkreślano

50 Tamże, s. 67-68. 
jego prymat. Brakowało w tych dyskusjach myśli o dynamice życia Kościoła i nastawienia ekumenicznego ${ }^{51}$.

Podobnie było z zagadnieniem wolności religijnej. W teologii rzymskiej była obecna teza o religii katolickiej uznawanej za religię państwową oraz teza o Kościele katolickim jako „miejscu” pełnej prawdy. W związku z tym w Kościele katolickim oraz wśród ojców soborowych hipoteza wolności religijnej cieszyła się poparciem zdecydowanej mniejszości, i to przyjmowana jako hipoteza pragmatyczna związana z obecnością Kościoła w świecie, dlatego z ograniczonym zaufaniem. Zwolennicy wolności religijnej wywodzą się ze Stanów Zjednoczonych. Uznawali oni to twierdzenie za podstawowe, a nie marginalne. Jezuita J.C. Murray, wybitny zwolennik wolności religijnej, miał przez 20 lat zakaz wypowiadania się. Na soborze został powołany do Sekretariatu ds. Jedności Chrześcijan jako peritus i był głównym redaktorem soborowego tekstu o wolności religijnej. Przed dyskusją w auli tekst musiał być zbadany i oceniony przez Komisję ds. Wiary. $\mathrm{W}$ tym celu powołano podkomisję, a ta jeszcze wzmocniła wymowę tekstu roboczego. Wobec tego kard. Ottaviani, przewodniczący Komisji ds. Wiary, przyjął taktykę spowalniania prac nad tymi problemami. O. Häring wprost walczył o skierowanie tekstu do dyskusji i to mu się udało ${ }^{52}$.

Papież Paweł VI w encyklice Ecclesiam suam, która uchodzi za jego programową, zajął się tematem dialogu Kościoła ze światem. Przeciwnikiem tego dialogu był bp Lefebvre i jego zwolennicy oraz niektórzy kurialiści watykańscy. O. Häring argumentował

\footnotetext{
51 Tamże, s. 68.

52 Tamże, s. 69-71.
} 
przeciwko nim, twierdząc, że błąd nie ma prawa obecności w nauce Kościoła, lecz może jedynie być cierpliwie znoszony tam, gdzie katolicka mniejszość może liczyć na tolerancję większości ${ }^{53}$.

W zagadnieniu wolności religijnej o. Häring widział dwa typy mentalności. Dla wyjaśnienia tej sytuacji potrzeba socjologii i psychologii społeczeństwa monopolistycznego oraz egzystencjalnej fenomenologii poszukiwania prawdy i wolnych od przemocy świadków poznanej prawdy. Pisał o tym w drugim tomie Frei in Christus, z podtytułem Der Weg des Menschen zur Wahrheit und Liebe ${ }^{54}$.

Uznanie wolności religijnej jest niemożliwe dla kontrolera prawowierności. Nie da się jej pojąć bez odpowiedzialności przed ziemską instancją. Nie uzna jej również ktoś zamknięty na możliwość zwątpienia także w dziedzinie prawd objawionych. Nie da się zrozumieć wolności religijnej bez jej faktycznej możliwości również w odniesieniu do religii niechrześcijańskich ${ }^{55}$.

O. Häring bez wątpienia miał wpływ na powstawanie dokumentów Soboru Watykańskiego II. To on domagał się, by każdy ojciec soborowy i peritus miał możliwość zajęcia własnego stanowiska na temat każdego tekstu bezpośrednio lub pośrednio, m.in. przy pomocy innych uczestników soboru. O. Häring uczestniczył w opracowywaniu wszystkich dokumentów przechodzących przez Komisję ds. Wiary, najczęściej udzielając konstruk-

53 „Der Irrtum hat kein Recht. Er kann nur geduldet werden, wo eine katholische Minderheit auf die Toleranz der Mehrheit angewiesen ist"; tamże, s. 71-72.

54 Tamże, s. 72.

55 Tamże. 
tywnej krytyki i formułując poprawki. Biskupi korzystali z jego pomocy jako znawcy języka łacińskiego, zwłaszcza w dyskusjach o znaczeniu terminów. Poza tym zapraszali go z wykładami oraz do udziału w dyskusjach m.in. nad czwartym rozdziałem Lumen gentium (o laikacie). O. Häring zaproponował Komisji ds. Wiary przeredagowanie tekstu z powodu wielu poprawek, by nadać mu charakter chrystocentryczny i podkreślić uczestnictwo wierzących w posłannictwie zbawienia, w profetycznym i kapłańskim urzędzie Chrystusa, w Jego posłuszeństwie (wolność). Tak poprawiony tekst został przyjęty prawie jednogłośnie.

W pracach nad dekretem o formacji do kapłaństwa Optatam totius o. Häring zaproponował odejście od legalistycznej teologii moralnej, którą postulowało wielu ojców soborowych, wyrażał sprzeciw wobec konkretnych tez teologicznych i domagał się dokładnego opisu potępianych treści. Zauważył też, że w teologii moralnej należy częściej korzystać z Pisma Świętego, a w wykładzie o powołaniu wierzących ukazywać owoce życia w miłości dla życia świata. Ten tekst został przyjęty prawie jednomyślnie.

Pod koniec pierwszego okresu obrad, gdy pracowano nad Gaudium et spes, o. Häring zwrócił uwagę na konieczność ustalenia celu i granic propozycji. Kard. Suenens i kard. Montini wskazali, że sobór nie powinien ograniczać się do uwzględniania tylko jednego kręgu i życia wewnątrzkościelnego. Właściwym jego zadaniem jest poszerzyć myśl o powołaniu Kościoła i jego stosunku do świata. Tymczasem podkomisja stwierdziła, że na podstawie materiałów przedsoborowych sporządzono projekt, który nikomu się nie podobał. W takiej sytuacji kard. 
Suenens zaprosił do Mechelin wybitnych teologów, wśród nich Karla Rahnera ${ }^{56}$, którzy zredagowali nowy, lepszy projekt ${ }^{57}$.

$\mathrm{Na}$ początku drugiego okresu prac soborowych Komisja ds. Wiary i Komisja ds. Apostolstwa Świeckich miały razem opracować projekt dokumentu o Kościele w świecie współczesnym. Rozpoczęto od dyskusji, który projekt przyjąć jako podstawę. O. Häring zaproponował, by dokument dotyczył współtworzenia historii i świata przez katolików oraz zrozumienia znaków czasu. Został więc powołany do sekretariatu koordynującego prace nad redakcją tekstu. W lutym 1964 roku, w Zurychu, o. Häring zaproponował, by pod pojęciem znaków czasu rozumieć znaki obecności Boga w świecie, znaki niekiedy alarmujące o sytuacji świata. Tę propozycję przyjęto ${ }^{58}$.

Drugim wielkim tematem był problem stosunku Kościoła do świata, inaczej mówiąc, powołanie czy zadanie Kościoła względem świata. Tu pojawiło się kilka wątków: małżeństwo i rodzi-

56 Karl Rahner (zm. 1984), jezuita, studiował filozofię we Fryburgu Bryzgowijskim, gdzie profesorem filozofii był Heidegger, który wpłynął na myśl Rahnera. Pracował na uniwersytecie w Wiedniu, potem w Innsbrucku, gdzie został profesorem zwyczajnym teologii dogmatycznej. W 1961 Jan XXIII powołał go na konsultora Komisji ds. Kultu Bożego i Dyscypliny Sakramentów, ale następnego roku Kuria Rzymska poddała jego publikacje cenzurze, zawieszonej w 1963 po papieskiej nominacji na eksperta soborowego. W czasie soboru był doradcą kard. Königa i kard. Döpfnera. Współpracował przy redagowaniu Lumen gentium i Gaudium et spes. W teologii uwage skierował na człowieka historycznego jako adresata Objawienia Bożego, mającego możliwość przyjęcia go, oraz na egzystencjalne uwarunkowania tego przyjęcia. Teologia stała się więc antropologią wyrażoną w języku egzystencjalnym, ale nie była antropomorfizmem. Zob. P. Sokołowski, I. Bokwa, M. Marczewski, Rahner Karl, w: Encyklopedia katolicka, t. 16, Lublin 2012, kol. 1156-1164.

57 B. Häring, Meine Erfahrungen mit der Kirche, dz. cyt., s. 74-75.

58 Tamże, s. 75. 
na, kultura, polityka, pokój i sprawiedliwość. W tym splocie problemów zadaniem o. Häringa było ustalenie konkretnych propozycji w aspekcie znaków czasu ${ }^{59}$.

Tekst wypracowany przez teologów w Zurychu stał się przedmiotem obrad plenarnych komisji mieszanej, do której należało 60 biskupów i tyle samo teologów oraz świeckich. Dyskusje były konstruktywne, przyjęto poprawki, a tekst został uznany za dobry i jako taki przyjęty przez ojców soborowych do dalszego opracowania $^{60}$.

W odniesieniu do małżeństwa powstał dodatek wysoko ceniony przez ojców soborowych i ostro skrytykowany przez kard. Heenana z Anglii. Kard. Cento, przewodniczący Komisji ds. Apostolstwa Świeckich, współprzewodniczący projektu „Kościół w świecie”, zaprzyjaźniony z o. Häringiem, zauważył, że nasilają się przeciw niemu wrogie działania, nie wyłączając fałszywych oskarżeń przed papieżem. Kard. Bea ${ }^{61}$ natomiast stwierdził, że komisja, mimo wielkiej liczby biskupów, nie jest reprezentatywna dla całego świata. Prawie wszyscy jej członkowie pochodzili z Europy, podczas gdy drugi i trzeci świat były reprezentowane bardzo ubogo. W wyniku tej krytyki ustalono listę biskupów

59 Tamże, s. 75-76.

60 Tamże, s. 76-77.

61 Augustin Bea (zm. 1968), jezuita, wykładał na Gregorianum i w Biblicum, którym kierował jako rektor w latach 1930-1949, propagując kierunek otwarty na nowe metody badań egzegetycznych wypracowanych przez protestanckich biblistów. Jako biblista od 1929 współpracował przy powstawaniu dokumentów Papieskiej Komisji Biblijnej i miał wpływ na treść encykliki Divino afflante Spiritu (1943). Drugim polem jego działalności był ekumenizm. Zapraszał na sobór członków innych wyznań chrześcijańskich, wziął udział w redagowaniu dekretu o ekumenizmie i konstytucji o Objawieniu Bożym. Zob. A. Cholewiński, S. Nagy, Bea Augustin, w: Encyklopedia katolicka, t. 2, Lublin 1985, kol. 159-160. 
z trzeciego świata. Paweł VI z zadowoleniem włączył do komisji bpa Câmarę z Brazylii, abpa Zoę z Kamerunu i abpa Wojtyłę. Ich działalność była bardzo ceniona ${ }^{62}$.

Tekst z Zurychu spotkał się z dobrym przyjęciem. Pojęcie znaków czasu pozwalało na odejście od ahistorycznego teologizowania, ale komisja ogólna się mu sprzeciwiała i dlatego powołano podkomisję do przedyskutowania go. Niektórzy teologowie (m.in. A. Hauptmann z Francji, P. Tucci z Włoch, Ch. Moeller i P. Hirschmann) je pomijali, ale dzięki Pawłowi VI powróciło, i to wzmocnione. O. Häring pracował nad rozdziałem „Małżeństwo i rodzina” i ustaleniami odpowiedniej podkomisji. W lutym 1963 roku przez dwa tygodnie różne podkomisje pracowały $\mathrm{w}$ Ariccia z udziałem - po raz pierwszy - kobiet zaproszonych za zgodą bpa Guano przez o. Häringa. Mniej więcej w tym samym czasie 200 biskupów postulowało uroczyste odrzucenie i potępienie komunizmu. O. Häring i bp Glorieux, przewodniczący Komisji ds. Apostolstwa Świeckich i współsekretarz wielkiej komisji mieszanej, uważali, że należy zrobić wszystko, co możliwe, by przeszkodzić temu politycznemu działaniu. W dyskusji zauważono, że dialog z całością marksizmu jest niesłychanie ważny. Chcąc ocenić komunizm jako ruch polityczny, gospodarczy i społeczny oraz jako ideologię, potrzeba jasnej analizy wszystkich kierunków. Jan XXIII wcześniej obiecał rządzącym w Moskwie, że sobór nie potępi komunizmu, a to w tym celu, by umożliwić udział w soborze, jako obserwatorom, przedstawicielom moskiewskiej Cerkwi. Odtąd bp Guano, kard. Garrone i bp Philips będą osobami decydującymi o kształcie konstytucji duszpasterskiej o Kościele. O. Häring natomiast odłożył prace w podkomisji ds. mał-

62 B. Häring, Meine Erfahrungen mit der Kirche, dz. cyt., s. 76-77. 
żeństwa i rodziny na rzecz pracy nad tekstem o pokoju, w którym była mowa o prawie sumienia do odmówienia służby wojskowej, o obronie wolnej od przemocy. Wprowadzono 50 poprawek i wielu biskupów przyjęło je z pełnym przekonaniem, zwłaszcza biskupi redemptoryści. Szczególnie ważne były poprawki do artykułu 16 „O sumieniu”63.

Pracom podkomisji ds. małżeństwa i rodziny towarzyszyły liczne konflikty. Jej konserwatywni członkowie, kard. Heenan i inni angielscy biskupi, zwolennicy encykliki Casti connubii, wkrótce przeszli na pozycję otwartą, akceptując zaproponowany tekst. Duży wkład w jego powstanie miał E. Schillebeeckx. Potem nastąpiło wspólne posiedzenie Komisji Soborowej ds. Małżeństwa i Rodziny z Papieską Komisją ds. Rodziny, Zaludnienia i Rozrodczości. W głosowaniu projekt otrzymał dwie trzecie głosów. Przed ostatnim głosowaniem doszło do następnego konfliktu. Patriarcha Kościoła melchickiego Maksymos oraz kardynałowie Suenens i Léger sprzeciwili się potępieniu antykoncepcji w Casti connubii. Problem dotyczył kontroli urodzeń i taki był początek kryzysu wokół encykliki Humanae vitae ${ }^{64}$. Paweł VI ogłosił ją 25 lipca 1968 roku i nie bez napięć, co jest zrozumiałe z uwagi na temat moralności małżeńskiej. Jest w niej mowa m.in. o łączności miłości z otwarciem na płodność, o dopuszczalności stosowania środków antykoncepcyjnych oraz o relacji sumienia do norm moralnych ${ }^{65}$.

W marcu 1963 roku Jan XXIII powołał Komisję ds. Zaludnienia. Składała się z ośmiu specjalistów. Potem Paweł VI dołączył

\footnotetext{
63 Tamże, s. 78-79.

64 Tamże, s. 86-87.

65 J.I. Saranyana, J.L. Illianes, Historia teologii, dz. cyt., s. 529.
} 
do niej kolejnych członków, tak że było ich 61, a nieco później 75. W Wielkim Poście 1964 roku o. Häring wygłosił rekolekcje dla papieża i Kurii Rzymskiej. Życzeniem papieża było otwarcie kurialistów rzymskich na wielkie tematy soboru. Redemptorysta na zaproszenie odpowiedział pozytywnie, mimo wielu zajęć związanych z soborem. Te rekolekcje, jak każde inne, były działaniem Ducha Świętego. Jednym z tematów była reforma liturgii i sprzeciw wobec ubóstwienia w niej łaciny. O wiele ważniejszym zagadnieniem było jednak małżeństwo i rodzina. Papież prosił o. Häringa o przedstawienie nauki św. Alfonsa o małżeństwie. W Casti connubii została wyłożona doktryna św. Augustyna o celu małżeństwa, którym jest zrodzenie potomstwa. Tymczasem stanowisko św. Alfonsa w tej kwestii jest diametralnie różne od rygoryzmu moralnego św. Augustyna. Twierdzi on, że pojęcie celu małżeństwa i aktu małżeńskiego ma trzy znaczenia. W pierwszym dotyczy wzajemnego oddania się sobie osób oraz umocnienia wiernością nierozwiązywalnego związku. Na drugim miejscu jest poczęcie nowego człowieka, a na trzecim zaspokojenie namiętności. Te dwa ostatnie są nie do wykluczenia, chociaż nie mogą i nie muszą być realizowane w każdym małżeńskim akcie współżycia. Takie rozumienie miało znaczenie również dla kazuistyki. W Papieskiej Komisji ds. Zaludnienia znalazła się interesująca grupa demografów, doradców małżeńskich, psychoterapeutów, członków ruchów rodzin chrześcijańskich (wśród nich małżeństwa z USA, założyciele Chrześcijańskiego Ruchu Rodzin) i ponad 20 teologów ${ }^{66}$. Na początku większość z 61, a późnej 75 członków komisji stała po stronie konserwatywnej, choć proponowano, by normy z Casti connubii pastoralnie osłabić,

66 B. Häring, Meine Erfahrungen mit der Kirche, dz. cyt., s. 84-87. 
ale ich nie odwoływać. Podobnie uważał o. Häring. Dzięki jego zabiegom nastąpił zwrot ku teologii św. Alfonsa, według którego każdy akt małżeński ma być wyrazem małżeńskiej miłości i pielęgnowaniem wierności małżeńskiej, ale nie musi być skierowany ku poczęciu i zrodzeniu nowego człowieka. Papież przyjął na audiencji członków Komisji ds. Zaludnienia w celu wspólnego poszukiwania rozwiązań tego problemu. Za encykliką Casti connubii opowiedzieli się jezuici Zalba, Ford, Lestapis oraz redemptorysta $\mathrm{z}$ Holandii, Visier, przy czym Lestapis i Visier proponowali łagodniejszą interpretację, a Ford i Zalba przyjęli skrajną postawę. Pozostali stwierdzali brak przekonujących argumentów. Podobnie było z problemem pigułek antykoncepcyjnych. Komisja nie doszła do wskazania papieżowi konkretnych metod, ponieważ było wiele różnych pigułek, tak co do składu, jak i sposobu działania. Papież oparł się na powszechnie uznawanych podstawach, na wypowiedziach o konkretnie stosowanych metodach. W punkcie wyjścia komisja uznała opinię Piusa XII, iż ważny jest wybór czasu poczęcia. Była to tzw. naturalna kontrola urodzin lub unikania (zapobiegania) niepożądanej ciąży. Większość członków komisji nie przeciwstawiała sobie naturalności i sztuczności zapłodnienia. Podobnego zdania byli niemieccy biskupi podczas synodu w Würzburgu, na którym stwierdzono, że regulację urodzin należy stosować po zbadaniu metody w świetle obiektywnych norm podanych przez Urząd Nauczycielski Kościoła (Synodenbeschluss: Christlich gelebte Ehe und Familie 2.2.2.6). Komisja nie oczekiwała od papieża jasnej wypowiedzi w kwestii pigułki progesteronu, ponieważ nie było jeszcze badań naukowych na odpowiednim poziomie. Przed soborem wielu małżonków wyrażało sprzeciw wobec ścisłego zachowania norm z Casti connubii. 
Pastoraliści i teologowie moraliści obawiali się jasno wypowiadać na ten temat, a to z powodu kontroli Świętego Oficjum. Tylko nieliczni odważnie prezentowali własne stanowiska oraz pytania i przemyślenia przed soborem i w pierwszym jego okresie. Po wystąpieniach kard. Suenensa i patriarchy Maksymosa sytuacja zmieniła się w ciągu jednej nocy. Na wiadomość, że papież postanowił potwierdzić i zaostrzyć normy z Casti connubii, ożywili się ich przeciwnicy, czego skutkiem była rezerwa niektórych teologów moralistów i pastoralistów wobec propozycji papieża. Jezuita Robertson, emerytowany arcybiskup Delhi, był zwolennikiem zawieszenia skrajnej normy z Casti connubii z racji eksplozji demograficznej i głodu w Indiach, ale inni biskupi angielscy oponowali. O. Häring natomiast radził, by dla dobra sprawy wstrzymali się od rozważania tych zagadnień. Do ostatniego posiedzenia komisji o. Häring został wprost zmuszony (odwołał dawno zaplanowane wykłady dla protestanckich pastorów w USA). Równocześnie ważni urzędnicy Świętego Oficjum wyrazili sprzeciw wobec redemptorysty i pod ich wpływem komisja zmieniła zdanie. O. Häring napisał list do przewodniczącego komisji, a G. Perico zauważył, że zawarł w nim to samo, co by powiedział. Sam o. Perico wypowiadał się jasno i dobrze prezentował opinie postępowych teologów komisji. Ostatnie jej posiedzenie zaowocowało dwoma raportami. Za pierwszym opowiedziało się ponad 90\% członków, ale później wydano drugi. Sformułowali go czterej wspomniani teologowie i równocześnie przyjaciele kard. Ottavianiego, ale żaden ze świeckich członków komisji nie podpisał się pod nim. Ten raport przekazano papieżowi ${ }^{67}$.

67 Tamże, s. 87-92. 
Paweł VI powołał komisję kontrolującą złożoną z kardynałów i biskupów; należeli do niej m.in. kard. Döpfner, kard. Heenan i bp Wojtyła. Kard. Döpfner reprezentował linię postępową, a kard. Heenan konserwatywną. Ale wkrótce kard. Heenan pogodził się z o. Häringiem i przyjął jego stanowisko. Poprawiony raport przyjęło dwie trzecie uczestników. Bp Wojtyła miał pewne wątpliwości. Stanowisko swe wyraził w rozprawie Miłość i odpowiedzialność, ale dopuszczał również ujęcie alternatywne, zgodnie z którym aktowi małżeńskiemu ukierunkowanemu na zrodzenie potomstwa towarzyszy radość z miłości, a antykoncepcji towarzyszy zwierzęca i grzeszna przyjemnośćc ${ }^{68}$. Problem regulacji poczęć i urodzeń był dyskutowany w latach pomiędzy soborem a ogłoszeniem encykliki Humanae vitae. Początkowo duże wrażenie wywarł wynik głosowania - dwie trzecie głosów komisji kardynałów i biskupów. Poświadczenie Ermenegilda Lio, wieloletniego konsultora Świętego Oficjum i doradcy kard. Ottavianiego, co do stanowiska papieża sprawiło, że przyjaciele franciszkanów z kolegium św. Antoniego w Rzymie opowiadali o. Häringowi, że papież, już prawie przekonany do raportu, zmienił zdanie. O. Lio i o. Hürth, redaktorzy tekstu przygotowanego dla soboru o celibacie, dziewictwie, małżeństwie i rodzinie, wyrazili w nim przekonanie, że miłość nie jest w małżeństwie istotnym czynnikiem. O. Lio był peritus w podkomisji soborowej ds. małżeństwa i rodziny. Biskupi z tej podkomisji postanowili nie brać udziału w pracach tak długo, dopóki o. Lio będzie uczestniczył w obradach ${ }^{69}$.

\footnotetext{
68 Tamże, s. 92-93.

69 Tamże, s. 93-94.
} 
O. Häring nie mógł się spotkać osobiście z papieżem, choć kilka razy prosił o audiencję, podobnie jak inni teologowie $\mathrm{z}$ komisji współodpowiedzialni za raport, ale tylko do czasu opublikowania go. Wyjątek stanowił Lambruschini, który w komisji głosował w grupie większościowej. Podczas konferencji prasowej o encyklice Humanae vitae reprezentował twierdzenie, że encyklika nie zalicza się do nauczania nieomylnego i niezmiennego. W dniu jej ogłoszenia o. Häring przebywał w Stanach Zjednoczonych. Dwaj dziennikarze - z „Time” i „Life” - pięć dni przed ogłoszeniem przekazali mu jej tekst z prośbą o udzielenie wywiadu na jej temat, ale ponieważ tekst zdobyli niezgodnie $\mathrm{z}$ zasadami moralności dziennikarskiej, postanowił tego nie robić. Humanae vitae podkreśla znaczenie miłości w małżeństwie, a antykoncepcja nie jest traktowana jak przestępstwo - było to „odkryminalizowanie” Casti connubii. Natomiast papież podtrzymał bezwyjątkową zasadę, iż akt małżeński jest skierowany na zrodzenie potomstwa i stąd dozwolona jest tylko naturalna regulacja urodzeń. W tym względzie fundamentalna jest konieczność odpowiednio uformowanego sumienia. Po ogłoszeniu encykliki niektórzy teologowie, lekarze, a nawet duchowni nosili się z zamiarem wystąpienia z Kościoła. „L'Osservatore Romano” opublikowało zaś opinię kard. Feliciego, że nieprzyjęcie encykliki jest już opuszczeniem Kościoła. W Waszyngtonie zebranie teologów powzięło plan wydania oświadczenia przeciw encyklice, ale o. Häring się pod nim nie podpisał. Sytuacja małżonków po ogłoszeniu encykliki stała się bardzo trudna, przede wszystkim z powodu zakazu sztucznego regulowania poczęć. O. Häring natomiast po nocy spędzonej na modlitwie postanowił, że byłoby grzechem przeciwko umiłowaniu Kościoła, gdyby wyraźnie wypowiadał swe stanowisko, 
które mogłoby mu przynieść osobiste następstwa, a zaufanie do Boga pozwala wiernie i wewnętrznie trwać w Kościele mimo sankcji. Sam był przekonany, że zakaz ten jest wykładem prawa Bożego i wynika z obowiązku życia zgodnego z własnym sumieniem. Ale - jego zdaniem - nie jest on wolą Boga i dlatego można żyć w wewnętrznym pokoju sumienia, i to nie jako katolik drugiej kategorii. Następnego dnia po ogłoszeniu encykliki „New York Times” opisał stanowisko o. Haringa, co powtórzyło wiele czasopism o światowym zasięgu. Dzięki temu wielu katolików pozostało w Kościele. Sam o. Häring opublikował artykuł The Encyclical Crisis: Contradictio. Can and Must be a Service to the Pope, który na prośbę kard. Döpfnera ukazał się w niemieckiej wersji w „Münchner Kirchenzeitung”. Artykuł ten odbił się wielkim echem i dla wielu stał się okazją do rachun$\mathrm{ku}$ sumienia. Sporo osób przyjęło go z zadowoleniem ${ }^{70}$. Tak oto o. Häring wprowadził po raz pierwszy palący problem pastoralny do mediów. Po tych oświadczeniach wielu biskupów nawiązywało z nim kontakt. Wziął udział w zebraniach biskupów w USA i Kanadzie. Przeprowadził również dwie serie wykładów, które gromadziły wielu słuchaczy i miały dobrą atmosferę ${ }^{71}$.

W samym Zgromadzeniu Najświętszego Odkupiciela stwierdzenia o. Häringa stały się inspiracjami pastoralnymi oraz wyrazem jego przywiązania i miłości do Kościoła. W poszczególnych prowincjach nastąpiło przejście od moralności rygorystyczno-

70 Das Zweite Vatikanische Konzil. Dokumente und Kommentare, Freiburg 1968, t. III, s. 424-446; B. Häring, Meine Erfahrungen mit der Kirche, dz. cyt., s. 94-98. Inne publikacje o. Häringa: Brennpunkt Ehe. Heutige Probleme und Perspektiven in Tradition und Lehramt; Krise um Humanae vitae. Teksty te szybko zostały przetłumaczone na inne języki.

71 B. Häring, Meine Erfahrungen mit der Kirche, dz. cyt., s. 94-99. 
-kazuistycznej do kerygmatycznej, przy czym starsi redemptoryści nie dokonali tego kroku. Trzy angielskojęzyczne prowincje opublikowały Das Gesetz Christi, jeszcze zakazane, ale dzięki temu tym bardziej studiowane i upowszechniane. Encykliki Casti connubii i Humanae vitae nie zostały dobrze przyjęte przez młodych redemptorystów, wręcz przeciwnie, część z nich opuściła Zgromadzenie i w ogóle stan duchowny. Teologia moralna o. Häringa cieszyła się zainteresowaniem w Brazylii, i to dzięki o. generałowi Tarcisio Amaralowi. W takiej sytuacji kard. Cicognani, sekretarz stanu Watykanu, wezwał o. Amarala, by usunął o. Häringa ze stanowiska i by o. Häring opowiedział się za encykliką, na co o. Amaral odpowiedział, że jest tylko kanonistą, a o. Häring ma w teologii moralnej dużo większe kompetencje. We wrześniu 1968 roku o. Häring powrócił ze Stanów Zjednoczonych i został wezwany do kard. Cicognaniego. W USA Watykan nie kontaktował się z nim, a nuncjusz Vagnozzi zgłaszał do Świętego Oficjum nieprawdziwe informacje o redemptoryście. Za to spotkał się z nim nuncjusz Clarizio z Ottawy, który wysoko ocenił wysiłki o. Häringa przeciwko wystąpieniom z Kościoła oraz jego rzeczowość i taką informację przekazał do kard. Cicognaniego. Ten spotkał się z o. Häringiem i przeprowadzili długą i rzeczową rozmowę. Sekretarz stanu poinformował go o zaniepokojeniu papieża $\mathrm{w}$ kwestii propagandy przeciwko celibatowi, jaką miał prowadzić o. Häring. O Humanae vitae rozmawiali bardzo delikatnie. Później kard Cicognani za pośrednictwem abpa Clarizio zapytał o. Häringa o encyklikę, a ten oświadczył, że jest ona do przyjęcia, i na tym zakończyła się ta sprawa. O. Häring opublikował w „Christ in der Gegenwart” z 1989 roku artykuł i encyklika została przyjęta przez wielkie episkopaty, ale 
nie $\mathrm{w}$ sensie norm z Casti connubii. O. Häring zaproponował odejście od ducha Casti connubii na rzecz nauczania św. Alfonsa i tradycji Kościoła prawosławnego, zwłaszcza pneumatologii prawosławnej, oraz ustaleń Synodu Biskupów zachodnioniemieckich. Do tego zwrócił uwagę na główne problemy pastoralne, to jest przepowiadanie o moralności, znaczenie chrztu, co wyraził w rekolekcjach dla pastorów ewangelickich i ich żon ${ }^{72}$.

19 kwietnia 1989 roku w watykańskiej Sala Stampa odbyła się prezentacja książki o. Häringa Frei in Christus. Prezentowali ją Giuseppe Alberigo, historyk z uniwersytetu w Bolonii, oraz Dalmazio Mongillo z Angelicum w Rzymie. Stwierdzili oni, że głównym celem publikacji jest przepowiadanie moralności opartej na Dobrej Nowinie ludziom ubogim i bardzo zalęknionym ${ }^{73}$. Wcześniej wydane opracowania o. Häringa budziły w kręgach kościelnych pewne niepokoje, choć nie było urzędowego upomnienia ani procesu sądowego w sprawie prawowierności doktrynalnej. Konsultorzy Świętego Oficjum wyraźnie mówili o wprowadzeniu na Index librorum prohibitorum jego wielkiego dzieła Das Gesetz Christi z 1954 roku, a trzy lata poźniej jego włoskiego przekładu (La legge di Christo). Wydawnictwo zaproponowało napisanie słowa wprowadzającego G.B. Montiniemu, ówczesnemu arcybiskupowi Mediolanu i późniejszemu papieżowi Pawłowi VI, który jednak odmówił, ponieważ nieprzychylnie nastawieni urzędnicy watykańscy mogliby obydwu zaszkodzić. Swego wykładu teologii moralnej o. Häring nie oparł na kodeksie prawnym, lecz wyszedł od spojrzenia na człowieka w aktualnym hi-

72 B. Häring, Meine Erfahrungen mit der Kirche, dz. cyt., s. 99-103.

„(...) das Hauptziel die Verkündigung der Frohbotschaft geprägten Moral an die Armen i Geängstigten"; tamże, s. 9. 
storycznym momencie jego rozwoju w świetle historii zbawienia oraz nauk humanistycznych. W In libertatem vocati estis (Rzym 1977), książce dedykowanej o. Häringowi z okazji jego 65. urodzin, wysoko oceniono perspektywę, w jakiej rozważał zagadnienia moralne: człowiek w świetle historii zbawienia i nauk humanistycznych ${ }^{74}$.

\section{Proces i inne doświadczenia z Kongregacją Świętego Oficjum}

Na kształt teologii w początkach XX wieku wpłynął modernizm, powodujący kryzys życia religijnego. Pojawił się we Francji, Włoszech i Anglii, a dotyczył filozofii, teologii i nauki społecznej. Treść tego pojęcia jest trudna do ustalenia. Modernizm jako wyraz czegoś, co nowe, sprzeciwiające się zastanemu, jest zjawiskiem normalnym w historii idei. W podobnym znaczeniu mówi się o progresizmie w przeciwieństwie do konserwatyzmu. W historii takie sytuacje zdarzały się często, ale nie miały nic wspólnego z błędami potępionymi przez Piusa X w 1907 roku w dekrecie Lamentabili i w encyklice Pascendi. Dlatego samo wyrażenie „modernizm” tak w XX wieku, jak i dziś jest dwuznaczne. W obu przypadkach charakteryzuje je jednak dialektyka historyczna. Tak więc zwolennicy integryzmu po ogłoszeniu encykliki $\mathrm{Pa}$ scendi otrzymali prawne podstawy do wyszukiwania w Kościele uczonych nazywanych modernistami, którzy jako zwolennicy nowoczesności staliby w pewnego rodzaju opozycji względem

74 „P. Häring ging in seiner Moral nicht von einem Gesetzkodex aus, sondern schaute auf den Menschen, wie er sich geschichtlich entwickelt, im Lichte der Heilgeschichte und auch der Humanwissenschaften"; tamże, s. 11 i 48 . 
tradycji chrześcijańskiej. Sam papież Benedykt XV wypowiedział się zresztą wyraźnie przeciwko integryzmowi w encyklice Ad beatissimi Apostolorum principis z $1914 \mathrm{roku}^{75}$. Kościelne potępienia modernizmu zmusiły do precyzyjnego określenia filozoficzno-teologicznego znaczenia tego pojęcia, które nawet przez poszczególnych jego przedstawicieli nie zawsze było jednoznacznie rozumiane, a jego źródłowa i teologiczna systematyka wskazuje na szereg błędów, na których opiera się modernizm XX-wieczny, oraz na częste wówczas tendencje w filozofii, religii, apologetyce, nauce biblijnej, historii dogmatów, dyscyplinie kościelnej i działaniach społeczno-politycznych. Te błędne teorie można sprowadzić do agnostycyzmu i immanentyzmu, których następstwem jest zniesienie nadprzyrodzonego charakteru wiary, dogmatów i Kościoła na rzecz wyłącznie wewnętrznego i należącego do istoty człowieka doświadczenia Boga, w przeciwieństwie do wiary wyłącznie zewnętrznej. Do takiej wiary przeżyciowej, do religii naturalnej, sprowadza się dane naturalnej i nadprzyrodzonej tradycji w Piśmie Świętym oraz w kościelnej tradycji w oparciu o subiektywistyczne i historyczno-ewolucyjne znaczenie. Kościół jako owoc kolektywnej religii naturalnej miał za zadanie przełożenie wewnętrznego doświadczenia religijnego na naukę i dyscyplinę racjonalną. Ponieważ każda epoka ma własny sposób przeżywania Boga, dlatego z ustanowienia Chrystusa istnieje kościelny Urząd Nauczycielski, utworzony przez wspólnotę chrześcijan, będący równocześnie świadkiem rozwoju dogmatów, a wiara i wiedza, Kościół i państwo pozostają dwoma oddzielonymi od siebie światami ${ }^{76}$.

75 R. Scherer, Modernismus, w: LthK, t. 7, Freiburg im Br. 1986, kol. 513.

76 Tamże, kol. 513-514. 
W dziedzinie filozoficznej i apologetycznej podstawowe błędy modernistyczne znalazły się w twórczości L. Laberthonnière’a i É. Le Roya. Pierwszy, w aspekcie teoretycznym bliski M. Blondelowi, był skłonny do zmiany znaczenia doświadczenia na subiektywnie przeżyciowy moralizm. Drugi reprezentuje antyintelektualistyczną filozofię H. Bergsona, w której tle stoi jeszcze nie przezwyciężony idealizm. W dziedzinie naukowo-biblijnej modernizm w radykalnej postaci był we Francji reprezentowany przez A. Loisy'ego, a w Anglii przez G. Tyrrella. Ten ostatni nadał modernizmowi systematyczny charakter. Inni uczeni, zafascynowani ówczesnym historyzmem i ewolucjonizmem, chcieli reformować jeszcze niezbyt rozwiniętą katolicką naukę biblijną, by w ten sposób dać dogmatyce nowy impuls i od wewnątrz dostosować objawienie boskie oraz kościelną tradycję do wymagań czasu. Sam F. von Flügel, mając zapatrywania charakterystyczne dla modernistów, uważał się tylko za pośrednika między francuskimi a angielskimi modernistami oraz między prawdziwie kościelną nauką a jej modernistycznymi odmianami ${ }^{77}$.

$\mathrm{Na}$ płaszczyźnie historyczno-dogmatycznej skrajny modernizm reprezentuje przede wszystkim J. Turmel. We Włoszech najważniejszym przedstawicielem tego nurtu był E. Buonaiuti, który w istocie reprezentował modernistyczną myśl francusko-angielską. W Niemczech modernizm nie znalazł zwolenników. Występujący tam katolicyzm reformowany w żadnym wypadku nie jest jego odmianą ${ }^{78}$.

Ponieważ twierdzenia modernistów nie zawsze były jednoznacznie pojmowane jako błędne i wiele zapatrywań przedsta-

\footnotetext{
77 Tamże, kol. 514.

78 Tamże, kol. 515.
} 
wiano, ukrywając się pod osłoną pseudonimów, Pius X czuł się zmuszony przedstawić normy odnoszące się przede wszystkim do nauczycieli i strażników teologii. W tym celu ogłosił encyklikę Pascendi, a w 1910 roku wprowadził przysięgę antymodernistyczną, w której zestawiono istotne punkty encykliki. Przewidziano również pozytywne plany wyjaśnienia przez modernistów powstałych problemów oraz uznano, że najlepsi teologowie katoliccy powinni wziąć udział w tych dyskusjach, ale niestety nie doszło do urzeczywistnienia tych wskazań ${ }^{79}$.

Modernizm w ostateczności jest nieprzezwyciężonym spotkaniem teologii tamtego czasu z ówczesną nową nauką i filozofią, dlatego po drugiej wojnie światowej znowu mówiono o neomodernizmie. Stale powracało w nim pytanie o możliwość pogodzenia nadprzyrodzonego charakteru Objawienia i Kościoła z ich historycznymi formami. Krytyka Pisma Świętego dokonana przez Loisy’ego i Tyrella ówczesną teologię liberalną powiązała $\mathrm{z}$ teologią profesjonalną, a dotąd istniejące sprzeczności historyczne rozwiązywano przez sprowadzenie wszystkich historycznych danych objawienia biblijnego i kościelnej tradycji do subiektywnego doświadczenia religijnego. Moderniści pojmowali element nadprzyrodzony jako obcy człowiekowi, przychodzący do niego z zewnątrz, bez żadnego wewnętrznego odniesienia, i to doprowadziło do całkowitego wyeliminowania czynnika nadprzyrodzonego. To zagubienie nadprzyrodzoności zostało potępione przez Kościół. Jednak pytanie o właściwy sposób interpretacji tajemnicy nadprzyrodzonego Objawienia Bożego i obecności Boga w Kościele i historii nie było przez stronę kościelną podejmowane. Zadowalano się bowiem wyjaśnieniem zachodzenia aktu

79 Tamże, kol. 515-517. 
wiary oraz ważnością nadprzyrodzonego charakteru bez zwracania uwagi na istotę ich zmiennego przenikania się. Z obawy przez subiektywizmem charakterystycznym dla filozofii idealistycznej nie dowierzano metodzie immanentnej, która zmierzała tylko do odnalezienia w świadomości zakładanych danych obiektywnych i subiektywnych, spotykających się w historii. Również wątpliwości co do pojęcia doświadczenia, zwłaszcza co do istnienia czysto subiektywnego doświadczenia i obiektywności poznania, rodziły rezerwę ówczesnej filozofii i teologii scholastycznej wobec autonomicznej historii oraz pozytywistycznie pojętej nauki. Poza tym brakowało wtedy dostatecznie rozwiniętej katolickiej nauki biblijnej, przede wszystkim hermeneutyki, która podjęłaby się usunięcia napięcia pomiędzy dogmatyką a historią, co później usiłował uczynić M.-J. Lagrange, zresztą podejrzewany o modernizm. O jedność wiary i myślenia teologia katolicka będzie się stale troszczyć, tak samo jak modernizm. Mimo jego błędnych metod będzie on poszukiwać tego samego, ponieważ uznawano to za główne zadanie nauki ${ }^{80}$.

80 Bodaj najważniejszym dokumentem papieskim, który zaważył na kształcie teologii współczesnej, był Syllabus Piusa IX. Jest to zbiór 80 błędów potępionych już wcześniej przez papieża w encyklice Quanta cura z 1864 roku (AAS 3 [1867], s. 168-176; D 1700-1780), związanych z sekularyzacją życia umysłowego i politycznego. 80 tez potępionych i udokumentowanych źródłami podzielono na 10 działów: 1) panteizm, naturalizm, skrajny racjonalizm; 2) racjonalizm umiarkowany; 3) indyferentyzm; 4) komunizm, tajne organizacje, towarzystwa biblijne; 5) błędy dotyczące Kościoła i jego praw; 6) błędy dotyczące mieszczańskiego społeczeństwa jako takiego i jego odniesienia do Kościoła (m.in. rozdział Kościoła od państwa); 7) błędy dotyczące naturalnej i chrześcijańskiej moralności; 8) błędy dotyczące małżeństwa chrześcijańskiego; 9) błędy dotyczące władzy papieża; 10) błędy związane z modernistycznym liberalizmem (przede wszystkim wolność sumienia i wyznania). Celem tego dokumentu był sprzeciw wobec laicyzmu, naturalistycznemu pojmowaniu 
Kongregacja Doktryny Wiary, ulegając pewnym grupom zmierzającym do tego od wielu lat, podjęła postępowanie sprawdzające prawowierność doktryny głoszonej przez Bernharda Häringa. Pojawiły się na ten temat informacje prasowe. „L'Osservatore Romano” i „Il resto Carlino”, omawiając Etica media o. Häringa, postawiły mu zarzut moralnego relatywizmu, z powodu włączenia do kryteriów oceny aktów moralnych aspektu historycznej sytuacji człowieka, a odsunięcia na dalszy plan słowa Bożego. Oskarżenia te o. Häring zdecydowanie odrzucił, wskazując na biblijne uzasadnienie w teologii moralnej, m.in. w Persona humana. Jak sam wskazał, z tego procesu płynie wniosek o konieczności reformy Kongregacji Doktryny Wiary, polegającej na

religii i absolutyzowaniu państwowej lub ludzkiej woli jako prawa boskiego. Wywołał on ożywione dyskusje, szczególnie we Francji, gdzie w kręgach integrystów i antyklerykałów pomijano niektóre zdania, wyrwano twierdzenia z kontekstu. Pewne uspokojenie przyniosła broszura F.A.Ph. Dupanloupa La Convention du 15 Sept. et l'Encyclique du 8 Dec. z 1865 roku, w której odróżniono tezę lub idealny obraz rzeczy od hipotezy lub podobieństw dostosowanych do potrzeb czasu. Wielu biskupów uznało tę interpretację za słuszną. Papież pochwalił tę broszurę oraz szczegółowy wykład na temat Syllabusa autorstwa L. Veuillota (L'illusion liberale, Paris 1865) i C. Schradera (Der Papst und die moderne Ideen, Wien 1865). Większość teologów odmawiała Syllabusowi charakteru nieomylnego nauczania.. Faktycznie ani nie jest on doktrynalnym rozstrzygnięciem, ani nie został uznany przez wszystkie episkopaty za nieomylne rozstrzygnięcie. Dla niektórych tez nie dano nawet kwalifikacji teologicznej. Dla ustalenia dokładnego stopnia błędów lub tylko ostrzeżeń bezwarunkowo należałoby zwrócić uwagę na źródła poszczególnych twierdzeń. Ta nowa kwalifikacja zdań w ich źródłowym kontekście jest też nieodzowna dla zrozumienia ich rzeczywistego znaczenia. Poza tym niektóre tezy, szczególnie dotyczące stosunków Kościoła do państwa lub tolerancji, są uwarunkowane czasowo i muszą być na nowo przemyślane w świetle rozwoju nauk, nie tylko kościelnych, od papieża Leona XIII do Soboru Watykańskiego II. Zob. R. Scherer, Modernismus, dz. cyt., kol. 517-518. 
dopuszczeniu obrony oskarżonego, oraz zaakceptowanie pluralizmu teologicznego. Uprzystępnienie tych dokumentów i pytań jest krokiem w kierunku wspólnej odpowiedzialności w Kościele i dla Kościoła. W ten sposób wzmocni się autorytet i wiarygodność Kościoła oraz orzeczeń Soboru Watykańskiego II ${ }^{81}$.

Dokumenty procesu Kongregacja Doktryny Wiary przekazała do Kurii Generalnej Zgromadzenia Redemptorystów w Rzymie, a stamtąd przez życzliwego mu generała dotarły do o. Häringa. Problemy będące przedmiotem tego procesu - odpowiedział - nie dotyczyły prawd wiary. Poza tym zabrakło konfrontacji jego poglądów z twierdzeniami innych teologów moralistów. W wywiadzie udzielonym „Corriere della sera” o. Häring, komentując ten proces, powiedział, że papieże przemijają, a Kuria trwa ${ }^{82}$.

Das Gesetz Christi, dzieło Bernharda Häringa wydane po niemiecku w 1954 roku, otwierające przed teologią moralną nowe drogi, nie spotkało się z pozytywną oceną Watykanu, ale nie padły też formalne oskarżenia. Der heilende Dienst natomiast zostało oparte na tekstach soborowych. Papież Paweł VI darzył o. Häringa zaufaniem, czego wyrazem było zaproszenie go do wygłoszenia rekolekcji w Watykanie w Wielkim Poście pierwszego roku jego pontyfikatu. Tymczasem Święte Oficjum zleciło zbadanie doktryny o. Häringa w celu znalezienia podstaw do oskarżenia. Papież wyraził zgodę na wszczęcie procesu, który toczył się jeszcze po jego śmierci i podczas ciężkiej choroby o. Häringa. Dopiero Jan Paweł II ostatecznie go zakończył ${ }^{83}$.

\footnotetext{
81 B. Häring, Meine Erfahrungen mit der Kirche, dz. cyt., s. 13-14.

82 Tamże, s. 14-15. „Die Päpste gehen, doch die Kurie bleibt”; tamże, s. 15.

83 Oryginał: B. Häring, Heilender Dienst. Ethische Probleme der modernen Medizin, Mainz 1972; polski przekład: W służbie człowieka. Teologia mo-
} 
Mimo tych zastrzeżeń o. Häring wszedł w skład komisji przygotowującej Sobór Watykański II. Profesor Hürth nakazał Świętemu Oficjum dokładne zbadanie dzieł o. Häringa, szczególnie Das Gesetz Christi, ale nie znaleziono w nim żadnego zdania heretyckiego. Mimo to nowa teologia moralna spotykała się z wrogą atmosferą i grupy teologów moralistów kierowały zarzuty pod adresem o. Häringa do generała redemptorystów i do Świętego Oficjum.

To wszystko działo się mimo dobrej woli papieży. Na przykład Jan XXIII w liście do generała Zgromadzenia oraz w przemówieniach podczas audiencji otwartych pozytywnie oceniał teologię moralną o. Häringa ${ }^{84}$. O. Häring zwracał uwagę na konieczność reformy w Kościele. Na pierwszym miejscu przypominał, że muszą być chronione prawa jednostki. Autorami zastrzeżeń byli prawowierni teologowie uważający się za szczególnie wiernych papieżowi. Takim był abp Parente, urzędnik Świętego Oficjum, autor listów przeciwko Y. Congarowi i o. Häringowi, podczas gdy Paweł VI darzył ich pełnym zaufaniem. O. Häring dał jasną odpowiedź na zarzuty wobec książki Der heilender Dienst, ale postępowanie procesowe - nie biorąc tego pod uwagę - wydało mu zakaz krytykowania Świętego Oficjum, publikowania oraz działalności publicystycznej. O. Häring zapewnił Watykan o swojej wierności Kościołowi ${ }^{85}$.

W 1977 roku kontynuowano w Watykanie badanie doktryny o. Häringa; na jej temat wypowiedzieli się też w In libertatem

ralna a etyczne problemy medycyny, tłum. M. Oziembłowski, Warszawa 1976; tenże, Meine Erfahrungen mit der Kirche, dz. cyt., s. 15-16.

84 Tenże, Meine Erfahrungen mit der Kirche, dz. cyt., s. 48.

85 Tamże, s. 16-17. 
vocati, dedykowanej mu księdze jubileuszowej, Y. Congar, K. Rahner i kard. Ratzinger. Publikacja dokumentów tego procesu wydaje się konieczna. Chodzi bowiem o ukazanie atmosfery i przejrzystości postępowania sądowego w Kościele, które mogłoby się stać modelem dla sądownictwa na świecie. Od listopada 1987 do kwietnia 1988 roku w Rzymie trwały wywiady G. Licheriego z o. Häringiem. Redemptorysta ukazał się w nich jako człowiek intensywnego życia naznaczonego poszukiwaniem prawdy i coraz lepszego poznania Chrystusa oraz niezłomny kapłan Kościoła, daleki od zamkniętej mentalności i klerykalizmu. Świadectwem tej postawy już w młodości jest jego wysiłek zmierzający do poznania Marksa i tła jego doktryny oraz krytyka ówczesnych podręczników teologii moralnej. Już w Das Gesetz Christi daje o sobie znać troska o zbawienie ubogich i bezdomnych. Wielkie znaczenie miały dla o. Häringa również doświadczenia wojenne oraz świadomość presji na duchownych. Jako teolog dostrzegał on rzeczywiste problemy księży, rolę kobiet w Kościele, los i cierpienia kobiet porzuconych przez mężów. Sobór Watykański II rzucił nowe światło na ówczesną sytuację. O. Häring jako członek komisji przygotowawczych miał wiele okazji do przemyślenia problemów dotykających ludzi. W okresie posoborowym natomiast do rangi głównego problemu urosło zagadnienie wolności religijnej, a to z kolei zwróciło uwagę na znaczenie możliwości wątpienia i kwestię nieomylności papieża. O. Häring stał się przeciwnikiem rygoryzmu w wykładzie encykliki Humanae vitae, zwłaszcza zakazu sztucznego zapłodnienia ${ }^{86}$.

O. Häring przybył do Rzymu w okresie jeśli nie upadku, to przynajmniej niskiego poziomu teologii katolickiej. Nie inaczej

86 Tamże, s. 16-19. 
było w Zgromadzeniu Najświętszego Odkupiciela. Nie cieszyło się ono ważnymi osiągnięciami w teologii moralnej; nie było ani nowych idei, ani nowych metod jej uprawiania. W pewien sposób świadczy o tym fakt, że żadna z książek redemptorystów nie dostała się na Index librorum prohibitorum. A w historii było tak, że teologowie, którzy dokonali jakiejkolwiek pionierskiej pracy, mieli do czynienia z tą najwyższą kościelną instancją kontrolującą. Sam o. Häring cieszył się w Watykanie szacunkiem i życzliwością tak ze strony papieży, jak i prawie wszystkich wysokich urzędników watykańskich. Miał tam wielu prawdziwych przyjaciół. Mimo to podczas soboru Kongregacja Świętego Oficjum nosiła się z zamiarem wyeliminowania jego wpływu na uczestników obrad. A ten wpływ był wręcz konieczny, zwłaszcza wobec jakości dokumentów przygotowanych dla soboru przez Święte Oficjum. Spośród 70 dokumentów żaden nie miał szans na przyjęcie przez ojców soborowych. Komisja przygotowująca schemat o liturgii reprezentowała odmienną od pozostałych orientację i kard. Lercaro oraz abp Bugnini - obaj zaprzyjaźnieni z o. Häringiem - po soborze znaleźli się na czarnej liście Kurii Rzymskiej, co zostało odczytane jako pierwszy znak alarmowy. Abp Parente, asessor w Kongregacji Świętego Oficjum, wezwał o. Häringa do wytłumaczenia się z zarzutu, jakoby w Stanach Zjednoczonych miał twierdzić, że posłuszeństwo Urzędowi Nauczycielskiemu Kościoła, nie wyłączając papieża, nie jest konieczne dla bycia prawowiernym katolickim. W odpowiedzi na ten zarzut o. Häring zauważył, że przed formalnym oskarżeniem przez Kongregację Świętego Oficjum podejrzanego należy przesłuchać, czego nie uczyniono. Poza tym pobyt o. Häringa w Stanach Zjednoczonych był śledzony na polecenie kard. Vagnozziego, delegata 
apostolskiego. Tymczasem o. Häring, podejrzewając taką możliwość, występował zawsze w towarzystwie któregoś z amerykańskich współbraci, który nagrywał wszystkie jego odczyty, a taśmy były do dyspozycji. Abp Parente z kolei polecił poddać dokładnej analizie wypowiedzi o. Häringa na temat sakramentu pokuty, ale nie znaleziono błędów teologicznych i do sprawy już nie powracano. Za te niesłuszne oskarżenia nikt o. Häringa nie przeprosił ${ }^{87}$.

Przyczyną kolejnego kontaktu o. Häringa z abpem Parente było poparcie, jakiego redemptorysta udzielił pewnemu biskupowi pozostającemu w sporze z Kongregacją Świętego Oficjum wobec papieża i niektórych osobistości watykańskich. Na zakończenie rozmowy o. Häring usłyszał od abpa Parente: „Wenn sie so weitermachen, gibt es für sie keine Carierra”. Następne zaproszenie od abpa Parente otrzymał w styczniu 1967 roku, to jest pomiędzy pracą w Komisji ds. Zaludnienia a ogłoszeniem Humanae vitae. Przedmiotem rozmowy był tym razem wywiad udzielony przez o. Häringa czasopismu „La Rocca”. Dziennikarka oczekiwała od niego jasnego sformułowania stanowiska wobec norm dotyczących kontroli urodzin z Casti conubii. O. Häring nie odpowiedział na to pytanie, lecz wyraził pełne zaufanie do papieża i przekonanie, że z pewnością nie będzie on w sprzeczności z postanowieniami soboru, co abp Parente uznał za negację wyższości papieża nad soborem. Na to o. Häring odpowiedział, że koherencja nauczania papieskiego z normami soboru przez niego zatwierdzonego bynajmniej nie jest negacją wyższości papieża nad soborem. Tym razem nie komentował encykliki Humanae vitae. Podczas ostatniego spotkania $\mathrm{z}$ abpem Parente o. Häring przypomniał mu trzy oskarżające go pisma, wśród nich list do

87 Tamże, s. 127-130. 
G. Rossiego przeciwko Y. Congarowi oraz o. Häringowi. Abp Parente chciał wiedzieć, skąd o. Häring miał te teksty, ale otrzymał interesującą odpowiedź: „(...) mir diese Dinge einfach zufliegen”. Na tym zakończyły się ówczesne problemy o. Häringa z Kongregacją Świętego Oficjum ${ }^{88}$.

Sam kard. Ottaviani zażądał pisemnie od o. Häringa, przebywającego w Stanach Zjednocznych, wyjaśnienia doniesień prasowych, jakoby duszpasterzom i wiodącym członkom chrześcijańskiego Ruchu Rodzin doradzał, że w zakresie regulacji poczęć należy respektować sumienie penitenta i poszukujących rady. Odpowiadając, o. Häring na potwierdzenie swego stanowiska przytoczył wiele cytatów z dzieł św. Alfonsa. Na tym zakończyła się ta sprawa. Było to już jedno z ostatnich wystąpień kard. Ottavianiego. 26 czerwca 1967 roku abp Parente został kardynałem, a jego miejsce w Kongregacji Świętego Oficjum zajął bp Philippe. W następnym roku kard. Ottaviani zakończył urzędowanie jako prefekt Kongregacji. Jego następcą został kard. Šeper z Zagrzebia. Philippe i Šeper podczas soboru mieli dobre kontakty z o. Häringiem ${ }^{89}$.

Właściwy proces Kongregacja Doktryny Wiary wytoczyła o. Häringowi 4 czerwca 1975 roku, kiedy to podczas zebrania kardynałów Kongregacji Nauki Wiary postanowiono przeprowadzić proces doktrynalny z powodu twierdzeń zawartych w pracy Etica medica. 13 czerwca 1975 roku papież zaaprobował to postanowienie. Pismo urzędowe w tej sprawie przesłano do o. Josefa Pfaba, generała redemptorystów, który przekazał je o. Häringowi. Warto tu dodać, że o. Pfab studiował teologię moralną i prawo

\footnotetext{
88 Tamże, s. 130-131; 141-142.

89 Tamże, s. 131-132.
} 
kanoniczne pod kierunkiem o. Häringa. 16 grudnia 1975 roku Kongregacja Doktryny Wiary skierowała pismo do o. Häringa, na które odpowiedział zaraz po powrocie ze Stanów Zjednoczonych i otrzymaniu go 5 lutego 1976 roku, odnosząc się do poszczególnych zarzutów. Kongregacja powzięła zamiar oskarżenia o. Häringa po publikacji w „L'Osservatore Romano” artykułu wprowadzającego do Roku Świętego, w którym przypisano mu twierdzenie negujące znaczenie nauczania papieskiego. Był to również główny punkt oskarżenia. W „L'Osservatore Romano" nie ma jednak dowodu na poparcie słuszności oskarżenia, stwierdził o. Häring. Wywiad spotkał się z żywą reakcją wysoko postawionych osobistości świata katolickiego, wyrażających sympatię pod adresem redemptorysty. Pismo Kongregacji Doktryny Wiary jest interesujące dla historyków, a rodzaj i sposób stawiania zarzutów oraz teksty oskarżonego są niezwyczajne w historii Kongregacji i prawników ${ }^{90}$.

Nie posiadając - z racji nieuporządkowania archiwaliów o. Häringa - pisma oskarżycielskiego Kongregacji Doktryny Wiary, należy się oprzeć na jego odpowiedzi na postawione mu zarzuty. Pierwszy sprowadza się do twierdzenia o minimalizowaniu, a nawet prawie całkowitym usunięciu roli Objawienia w pracy o. Häringa (chodzi o $W$ stużbie człowieka. Teologia moralna a etyczne problemy medycyny), wobec czego zaproponowana przez niego etyka lekarska nie ma chrześcijańskiego charakteru. Na to o. Häring przywołał tytuł francuskiego przekładu tego dzieła: Perspective chretienne pour une médicine humaine (Paris 1975). Przypomniał też wysokie wymagania stawiane chrześcijańskiej moralności w krytykowanej książce. Nie ma

90 Tamże, s. 132-133. „Die Klärung dieser Angelegenheit könnte für die Kirche providentiell sein"; tamże, s. 133. 
w niej mowy o żadnym osłabieniu elementów chrześcijańskich. W piśmie Kongregacji natomiast chodzi o zagadnienia z zakresu teologii fundamentalnej, dlatego nie trzeba tu poszukiwać dowodów dla poszczególnych tez. Książka ta w zamiarze o. Häringa miała być próbą opracowania chrześcijańskiej etyki i stąd omówiwszy zagadnienia ogólne, przedstawił problem sensu życia, śmierci, choroby czy uzdrowienia, zawsze wyraźnie powołując się na Pismo Święte ${ }^{91}$.

Do tego Kongregacja postawiła mu zarzut natury ogólnej, a mianowicie niedoskonałości i niezupełności opracowania podjętego tematu. Tutaj o. Häring po prostu zapytał, czy niedoskonałość jakiegokolwiek opracowania może być podstawą oskarżenia. Zresztą taki zarzut można postawić każdemu autorowi, a tym bardziej pierwszej próbie opracowania nowego zagadnienia. O. Häring - jak sam napisał - moralność pojmuje zgodnie z Optatam totius, a więc jako ludzkie działanie karmione słowem Bożym. Zarzut jest więc niesłuszny. Podobnie potraktował zarzut niezupełności, ponieważ dotychczas nikt nie opublikował takiej książki. Była to pierwsza próba, dlatego z natury rzeczy niezupełność dotyczyła tak zakresu podjętych zagadnień, jak i sposobu ich rozwiązywania ${ }^{92}$.

Drugi zarzut Kongregacji Doktryny Wiary sprowadzał się do braku pogłębionego omówienia zagadnienia naturalnego prawa moralnego. Ale - ponownie odpowiedział o. Häring - moż-

91 „(...) wird der Beitrag der Offenbarung minimalisiert und fast ganz entleert. (...) Die Anklage lässt mich sprachlos. Ich bitte die Glaubenskongregation, mir irgenteinen traditionellen Text der katholischen ärztlichen Ethik zu nennen, in dem dieses Anliegen mit so viel Sorgfalt, auf so vielen Seiten und mit so hohen Ansprüchen behandelt wird"; tamże, s. 133-134.

92 Tamże. 
na go postawić wielu autorom. On sam w wielu publikacjach podejmował problem chrześcijańskiego rozumienia naturalnego prawa moralnego. Wykład tej kwestii w Etica medica miał mieć znaczenie dla dialogu z pracownikami służby zdrowia, a jej celem była ewangelizacja współczesnego świata, zatem książka musiała być dostosowana do poziomu wiedzy adresatów ${ }^{93}$.

Przedmiotem trzeciego zarzutu była krytyka twierdzenia św. Tomasza z Akwinu (Sum.Th. I-II, q. 94, a. 2). Odpowiadając, o. Häring napisał, że często pozytywnie oceniał poglądy św. Tomasza. Tu chodzi o krytykę twierdzenia, że człowiek ma skłonności do rzeczy i działań zgodnych z jego naturą, którą jednak współposiada z pozostałymi istotami żywymi (animalia), dlatego tak rzeczy, jak i działania należą do zakresu prawa naturalnego i sama natura w pewien sposób informuje o nich człowieka. Do zakresu tych dążeń (skłonności) należy np. dążenie do płciowego zjednoczenia mężczyzny z kobietą czy rodzenie potomstwa. Odpowiadając, o. Häring szuka sposobów rozumienia tego twierdzenia św. Tomasza i zauważa, że większość teologów i antropologów podkreśla ludzki wymiar seksualności i moralności seksualnej, i w ten sposób dołączają do rozumienia tego tekstu tak, jak go rozumiał o. Häring. Dodał nawet, że umiłowanie Kościoła i posługa zbawienia zobowiązują do brania pod uwagę wypowiedzi i pojęć, które mogłyby zakwestionować wiarygodność przepowiadania Kościoła ${ }^{94}$.

W następnym zarzucie chodzi o pojęcie znaków czasu. Według Kongregacji Doktryny Wiary, o. Häring posługuje się tym terminem dwuznacznie, ale czy tak jest rzeczywiście? Otóż au-

\footnotetext{
93 Tamże, s. 134.

94 Tamże, s. 134-135.
} 
tor tłumaczy, że nie mówił o duchu, lecz o znakach czasu, a to wyrażenie zna każdy wykształcony Włoch. Nadto o. Häring pisał też o pozytywnych elementach ducha czasu, o uściśleniu moralnych przekonań poprzez opracowanie Kodeksu lekarskiego przez samych lekarzy. I stąd zadał pytanie, czy ktoś zbadał zgodność oskarżenia $z$ jego poglądami i czy można zamiennie używać pojęcia znaków czasu i ducha czasu. Sam też na nie odpowiedział, koncentrując się na pierwszym z nich. Pod tym pojęciem, jakże ważnym dla Kościoła, Sobór Watykański II rozumie znaki obecności Boga w świecie (Gaudium et spes), a często loci theologici, przez które Bóg objawia swoją wolę. Te znaki czasu pojmuje się w kontekście objawienia się Chrystusa ${ }^{95}$. Chrystus jest przecież ostatecznym i decydującym słowem Boga do ludzi. Tego nic ani nikt nie jest w stanie zmienić, a On jest miłością skierowaną do Ojca i ludzi. Ziemskie życie Chrystusa jest kluczem zbawienia na wszystkie czasy. Historia natomiast jest wzrostem znajomości Chrystusa dzięki Jego dziełu i działaniom świata i Kościoła w historii ${ }^{96}$.

Bodaj najcięższym zarzutem postawionym przez Kongregację Doktryny Wiary o. Häringowi był zarzut etycznego relatywizmu. Zgodnie z tym stanowiskiem filozoficznym kryteria dobra lub zła czynu ludzkiego wynikają wyłącznie z historycznej sytuacji, w jakiej został on dokonany. Tymczasem - odpowiada o. Häring - zawsze był przeciwnikiem historyzmu i dlatego za-

95 Por. B. Häring, Morale ed evangelizzazione del mondo di oggi, Roma 1974.

96 Tenże, Meine Erfahrungen mit der Kirche, dz. cyt., s. 135-137. „Das Wirken Gottes ist immer in seinem Wort. Und deshalb haben wir auf dieses Wort zu hören"; tamże, s. 137. Por. tenże, Wie als Christ handeln?, w: tenże, Gott, Mensch, Universum, red. J. Hüttenbügel, Graz-Wien-Köln 1974, s. 632-633. 
rzut ten jest bezpodstawny i niesprawiedliwy. Ponadto o chrześcijańskim tworzeniu norm pisał $\mathrm{w}$ innym opracowaniu (Wie als Christ handeln? $)^{97}$.

Za kluczowy dla procesu o. Häring uznał zarzut, jakoby miał twierdzić, że Urząd Nauczycielski Kościoła nie ma kompetencji koniecznych do wypowiadania się w zagadnieniach dotyczących moralności. To, co w tym temacie napisał o. Häring, jest tożsame z treścią przemówienia Jana XXIII na otwarcie Soboru Watykańskiego II. Do tego należy dodać potwierdzenie potrzeby odpowiedniej hermeneutyki dla interpretacji dokumentów Magisterium i tego, by całkowicie nowe problemy rozważać w odpowiednim świetle. Tak samo zresztą wypowiedziała się Kongregacja Doktryny Wiary w Mysterium Ecclesiae. Zarzut Kongregacji zauważa o. Häring - byłby słuszny przy założeniu ponadczasowości wypowiedzi Urzędu Nauczycielskiego Kościoła na tematy moralne, dla których nie potrzeba szczególnej hermeneutyki. I tutaj zadaje następujące pytania: czy ktoś w Kongregacji zbadał zasadność tego zarzutu? Przecież sam papież we wspomnianym przemówieniu zajmował się tym problemem. Papież ze swej strony wzywa do dawania świadectwa miłości. Poza tym o. Häring domyślał się źródeł tych oskarżeń. W czasie soboru podobne zarzuty płynęły ze strony Świętego Oficjum, ale o. Häring miał nagrania wszystkich swoich wykładów i wystąpień. Niktze Świętego Oficjum nie skierował do niego słowa przeprosin. Odpowiadając na ten zarzut Kongregacji, o. Häring stwierdził najpierw ogólnie, że poważnie traktuje nauczanie papieskie. Jeśli inni teologowie nie wypowiadają pod adresem Kurii Rzymskiej krytycznych słów, to tylko dlatego, że nie traktują jej poważnie. Oskarże-

97 B. Häring, Meine Erfahrungen mit der Kirche, dz. cyt., s. 137; por. tenże, Wie als Christ handeln?, dz. cyt., s. 640-647. 
nia wobec o. Häringa były niesłuszne i miał wątpliwości, czy papież je znał. Wobec tego poprosił go o audiencję. O. Häring wiele razy deklarował swą wierność Kościołowi, a w działalności teologicznej chodziło mu o ukazywanie możliwości bycia w Kościele ludzi, którzy mieli wątpliwości bądź inne trudności. Zresztą zauważył - podobnie było z Rosminim i J.H. Newmanem. Chodziło mu także o to, by urzędnicy kościelni byli dobrymi i uczciwymi ludźmi, zdolnymi innym oszczędzić problemów, jakich sam doświadczał ${ }^{98}$.

Odpowiedzią na zarzut siódmy jest przypomnienie konieczności badań interdyscyplinarnych. W ten sposób medycyna zostanie poddana krytyce ze strony samych medyków i równocześnie będzie prowadzony dialog interdyscyplinarny. Medycyna w swej historii była poszukiwaniem dobra i prawdy, ale zabrakło dialogu lekarzy z wydziałami teologicznymi i Magisterium. Oskarżyciele o. Häringa nie brali pod uwagę ewentualnych powiązań medycyny i teologii. A tymczasem czwarte wydanie Etica medica ukazało się wcześniej niż pismo oskarżycielskie, a o. Häring pisał w nim o wspólnej medycynie i teologii trosce o ochronę dziecka poczętego. Poza tym zauważył, że dialog w żadnej mierze nie niweczy autonomii tych nauk, a do tego teologia jako służba zbawieniu nie może ignorować tego, co dają ludziom do dyspozycji medycyna i inne nauki. Stąd wyprowadził wniosek o konieczności dialogu Magisterium z lekarzami. To samo przekonanie - pisze - jest zawarte w niektórych wypowiedziach Urzędu Nauczycielskiego Kościoła, m.in. Lumen gentium (32-37), Gaudium et spes (44), Ecclesiam suam. Kościół dla wypełnienia zbawczej misji potrzebuje dialogu teologów i Magisterium. Teologia zresztą

98 Tenże, Meine Erfahrungen mit der Kirche, dz. cyt., s. 137-140. 
służy pomocą Kościołowi ${ }^{99}$. Tu wypada przypomnieć nauczanie papieża Jana Pawła II w tej materii. Wielokrotnie mówił przecież o współpracy teologów $\mathrm{z}$ reprezentantami różnych nauk, stwierdzając równocześnie, że nauki te mogą ich inspirować do poszukiwania nowych rozwiązań dawnych problemów, a także do odkrywania nowych kwestii teologicznych ${ }^{100}$.

Dwa ostatnie zarzuty były związane z encykliką Humanae vitae. Pierwszy suponował sprzeciw o. Häringa wobec niej. W odpowiedzi o. Häring stwierdził, że w piśmie oskarżycielskim nie ma mowy o konkretnych sformułowaniach z Etica medica, zatem proces dotyczył prawdopodobnie jego intencji. Przy okazji przypomniał, że napisał to samo, co episkopaty w instrukcjach pastoralnych dotyczących tej encykliki, dlatego jeżeli jest oskarżony, to wraz z nim większość teologów, ale wtedy Kościół utraciłby autorytet, a przecież wierność Kościołowi jest nie do przyjęcia bez absolutnej poprawności ${ }^{101}$. Po opublikowaniu Humanae vitae $\mathrm{w}$ środowisku lekarzy pojawiła się ostra reakcja, włącznie z zapowiedzią wystąpień z Kościoła. Teksty o Humanae vitae o. Häring jeszcze przed ich publikacją przedstawił kard. Cicognaniemu, sekretarzowi stanu, od którego otrzymał wiadomość, że papież bardzo boleśnie odczuł walkę redemptorysty przeciw celibatowi - ale ta walka w ogóle nie miała miejsca. Historia z Humanae vitae była zdaniem o. Häringa spowodowana „układami w Kurii Rzymskiej"102.

99 Tamże, s. 140-141.

100 Przemówienia i homilie Ojca Świętego Jana Pawła II, Kraków 1997 (zwł. rozdział Przyszłość człowieka zależy od kultury. Jan Paweł II do ludzi nauki $i$ kultury, s. 267-354).

101 B. Häring, Meine Erfahrungen mit der Kirche, dz. cyt., s. 141.

102 Tamże, s. 141-144. 
Ostatni zarzut dotyczył natury aktu seksualnego. O. Häring stwierdził w odpowiedzi, że pisał o całości aktu seksualnego, a nie jego poszczególnych elementach, i dlatego uznał, że ma to być akt ludzki, a nie akt podobny do aktów zwierzęcych - jako taki zawiera elementy biologiczne i psychiczne, a to znaczy, że dla jego zbadania konieczna jest interdyscyplinarność medycyny, nauk przyrodniczych i teologii ${ }^{103}$.

Dokładnie miesiąc później - 5 marca 1976 roku - kard. Šeper, prefekt Kongregacji Doktryny Wiary, odpowiedział o. Häringowi na powyższy list. Miało to na celu - pisze kardynał - lepsze poinformowanie o. Häringa o przedmiocie sporu i tym samym przywrócenie spokoju, a postępowanie Kongregacji Doktryny Wiary dotyczy jedynie zbadania doktryny i nie ma charakteru procesu karnego, jest też tajne. Na co o. Häring zwrócił uwagę, że dotychczasowe postępowanie odbyło się bez wysłuchania podejrzanego i zasięgnięcia opinii innych teologów. Prawdopodobnie chodziło tu o obronę określonej teologii ${ }^{104}$.

Na tym jednak spór się nie skończył. Jego następny etap dotyczył Persona humana. W związku z tym 1 maja 1976 roku o. Häring napisał list do kard. Šepera, w którym wyraźnie stwierdził, że u podstaw sporu leży określona teologia, a on akceptuje podstawowe zagadnienia tego dokumentu, co wywołało zdziwienie i niedowierzanie, bo prasa międzynarodowa zareagowała negatywnymi sądami. Refleksje o. Häringa o Persona humana stanowią uzupełnienie jego odpowiedzi na oskarżenie i są wyrazem troski duszpasterskiej oraz spełnieniem próśb wielu redakcji ${ }^{105}$.

103 Tamże, s. 144.

104 Tamże, s. 145-147. „Geht es hier nicht um einen Richtungskampf einer ganz bestimmten Theologie?"; tamże, s. 147.

105 Tenże, Reflexionen zur Erklärung der Glaubenskongregation über einige Fragen der Sexualitaet, „Theologische Quartalschrift” 124 (1976), s. 121-126. 
Ten artykuł spotkał się z bardzo pozytywnym przyjęciem. Prof. Richard Egenter, zainteresowany zagadnieniami pastoralnymi, podkreślił jego otwartość. Inny teolog moralista za pożytek z tego artykułu, dzięki jego jasności, uznał pomoc w rozwiązaniu napięcia pomiędzy nauką a Nauczycielskim Urzędem Kościoła, ale równocześnie artykuł był zakotwiczony w opcji na rzecz aktualnego Kościoła. Natomiast Kongregacja Doktryny Wiary przyjęła go z niechęcią ${ }^{106}$.

Innym powodem napięcia pomiędzy Kongregacją a o. Häringiem był tygodnik „Famiglia Cristiana” - czytany, co ważne, przez 7-9 milionów ludzi. Otóż o. Häring co tydzień odpowiadał jego czytelnikom na pytania o chrześcijański kształt życia. 23 maja 1976 roku odpowiedział małżonkom na pytanie o charakter norm z Humanae vitae zakazujących antykoncepcji. Odpowiedź była krótka i sprowadziła się do zacytowania dłuższego zdania z zapisu stanowiska episkopatu francuskiego na ten temat. Podobne stanowisko zajęło wiele episkopatów i synod biskupów zachodnioniemieckich. O. Häring nie spodziewał się, że to właśnie wydarzenie doprowadzi do wzrostu napięcia pomiędzy nim a Kongregacją Doktryny Wiary, czego wyrazem były dwa listy kard. Šepera, z 3 lipca i 11 listopada 1976 roku ${ }^{107}$.

Pierwszy z nich jest dokumentem o szczególnym znaczeniu historycznym. Napisany po francusku został skierowany do biskupów francuskich i do tych, którzy na nich się powołują. Kongregacja Doktryny Wiary wyraźnie opowiedziała się tu za zakazem sztucznej kontroli urodzeń. Nie wolno więc myśleć o dopuszczeniu przekroczenia obiektywnej skali wartości (epikeia).

106 Tenże, Meine Erfahrungen mit der Kirche, dz. cyt., s. 141-149.

107 Tamże, s. 149. 
Co najwyżej do przyjęcia jest możliwość zmniejszonej winy subiektywnej. List ten przesłano również o. Häringowi jako odpowiedź na zasygnalizowany problem. Jego odpowiedź w „Famiglia Cristiana” z 23 maja 1976 roku, z powołaniem się na tradycyjną naukę, co uczynili również biskupi francuscy, brzmiała: „(...) w konflikcie obowiązków obowiązek ważniejszy, bardziej pilny ma pierwszeństwo. $W$ takim razie mogłoby się zdarzyć, że małżonkowie $\mathrm{z}$ dobrym sumieniem i bez winy wybraliby najbardziej skuteczny środek regulujący poczęcie”. W nocie pastoralnej Episkopatu francuskiego na temat Humanae vitae z 1968 roku (par. 16) - zauważa o. Häring - brakuje doprecyzowania na temat obiektywnego i subiektywnego aspektu konfliktu sumienia. Przedstawił je kard. Renard, przewodniczący Komisji ds. Rodziny w Episkopacie francuskim, w „Documentation Catholique” w 1968 roku (kol. 2174), co uszło uwagi o. Häringa. Nota ta stwierdza: to, co zawsze może być subiektywną winą, a więc akt antykoncepcyjny, nigdy nie może być obiektywnie dobry. Kongregacja Doktryny Wiary uznała stanowisko biskupów francuskich, ale tylko z powyższą poprawką, a od o. Häringa oczekiwała opublikowania w „Famiglia Cristiana” oraz agencji prasowej ANSA i w czasopismach sprostowania. Ten tekst o. Häring otrzymał od przełożonego generalnego Zgromadzenia i został on wraz z całą dokumentacją opublikowany w „Fede. Storia. Morale” ${ }^{108}$. 11 listopada 1976 roku kard. Šeper zwrócił się do generała o. Pfaba z prośbą o nakłonienie o. Häringa do większej roztrop-

108 Tamże, s. 150-151. 14 lipca 1976 G.B. Guzzetti, teolog moralista z Mediolanu, opublikował w „L'Osservatore Romano” artykuł polemiczny przeciw o. Häringowi (Neue Angriffe auf Humnae vitae), w którym brak informacji o cytowaniu przez niego oficjalnego stanowiska Episkopatu francuskiego, a powołanie się na rozstrzygnięcia wielkich episkopatów uznano za karygodne; tamże, s. 151. 
ności w wypowiedziach na temat małżeństwa i rodziny ${ }^{109}$, i na tym skończył się spór o. Häringa z Kongregacją Doktryny Wiary. Jego powodem - jak sam napisał w Moraltheologie für das dritte Jahrtausend - było pragnienie niektórych wpływowych osobistości w Kurii Rzymskiej, aby ponownie uznano za jedyne słuszne stanowisko zajmowane przez nich w soborowej komisji przygotowawczej, co wielu chrześcijanom pozostającym pod wpływem przełomowych idei Soboru Watykańskiego II nie pozwalało się z nimi oraz z przedsoborowym Kościołem identyfikować ${ }^{110}$.

\section{Zamiast zakończenia}

W niektórych podręcznikach do nauki języka niemieckiego pierwsze zdanie brzmi: „Aller Anfang ist schwer” - my powiedzmy dziś inaczej: „Anfang in allen Dingen ist schwer”. Wobec tego trudności, jakie napotykał o. Bernhard Häring w poszukiwaniu i tworzeniu nowej - posoborowej - teologii moralnej, wydają się czymś normalnym. Zresztą nie jest on wyjątkiem. Wspomnijmy św. Tomasza z Akwinu i potępienie przez Stefana Tempiera, profesora teologii, kanclerza Uniwersytetu Paryskiego i biskupa Paryża, ponad 20 jego tez, z czego później - w trakcie procesu

\section{Tamże, s. 152.}

110 „Leider beweisen zahlreiche Ereignisse nach dem Konzil, dass einflussreiche Persönlichkeiten der römischen Kurie versucht haben, ihre Einstellung und ihre ganze im Rahmen der Vorbereitungskommission dargestellte Meinung wiederherzustellen und durchsetzten. Allerdings muss gesagt werden, dass der Umschwung beziehungsweise Umbruch während des Konzils so tiefgreifend war, dass et für viele Christen schwierig war, sich damit zu identifizieren. Moraltheologie und Kerygmatik folgten mit Enthusiasmus den grossen Linien des Konzils"; B. Häring, Moraltheologie für das dritte Jahrtausend, dz. cyt., s. 15. 
beatyfikacyjnego - trzeba się było wycofać i przyznać do błędu. „Dawne” bowiem nigdy nie chce opuszczać sceny, zwłaszcza w przypadku wielowiekowej tradycji, ale wcześniej czy później musi to uczynić i ustąpić miejsca „nowemu”.

I na koniec jeszcze jedna uwaga. Teologia moralna musi się bezpośrednio oprzeć na antropologii filozoficznej i teologicznej, na teorii wartości i etyce, a te nauki podlegają ciągłemu rozwojowi, czemu teolog moralista nie może ani zaprzeczyć, ani tego pominąć. 
A. Uniwersytet Papieski T.6. Jana Pawła II 